Prepared in cooperation with the Georgia Department of Natural Resources, Environmental Protection Division

\title{
Methods for Estimating Selected Low-Flow Frequency Statistics and Mean Annual Flow for Ungaged Locations on Streams in North Georgia
}

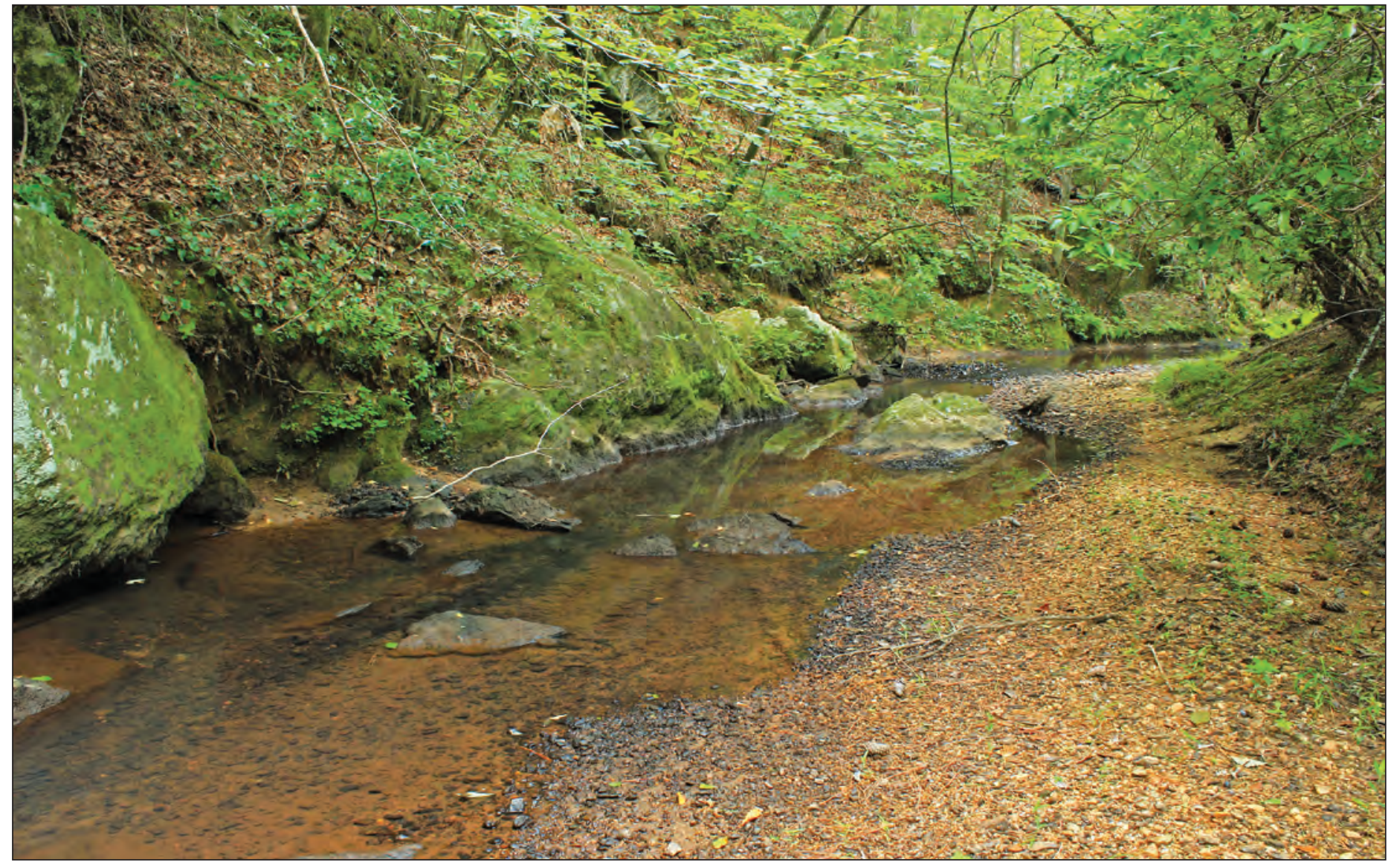

Scientific Investigations Report 2017-5001 
Cover. Bluffy Creek in Paulding County, Georgia, August 6, 2011. Photograph by Alan M. Cressler, U.S. Geological Survey. 


\section{Methods for Estimating Selected Low-Flow Frequency Statistics and Mean Annual Flow for Ungaged Locations on Streams in North Georgia}

By Anthony J. Gotvald

Prepared in cooperation with the Georgia Department of Natural Resources, Environmental Protection Division

Scientific Investigations Report 2017-5001 


\section{U.S. Department of the Interior SALLY JEWELL, Secretary}

\section{U.S. Geological Survey Suzette M. Kimball, Director}

\section{U.S. Geological Survey, Reston, Virginia: 2017}

For more information on the USGS - the Federal source for science about the Earth, its natural and living resources, natural hazards, and the environment—visit http://www.usgs.gov or call 1-888-ASK-USGS.

For an overview of USGS information products, including maps, imagery, and publications, visit http://store.usgs.gov/.

Any use of trade, firm, or product names is for descriptive purposes only and does not imply endorsement by the U.S. Government.

Although this information product, for the most part, is in the public domain, it also may contain copyrighted materials as noted in the text. Permission to reproduce copyrighted items must be secured from the copyright owner.

Suggested citation:

Gotvald, A.J., 2017, Methods for estimating selected low-flow frequency statistics and mean annual flow for ungaged locations on streams in North Georgia: U.S. Geological Survey Scientific Investigations Report 2017-5001, 25 p., https://doi.org/10.3133/sir20175001.

ISSN 2328-0328 (online) 


\section{Contents}

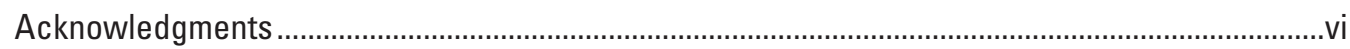

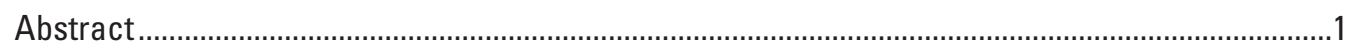

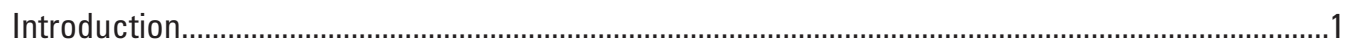

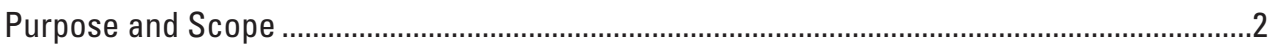

Description of the Study Area ....................................................................................................

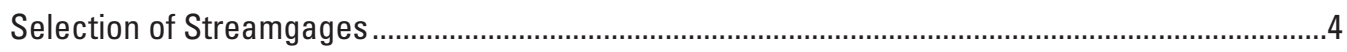

Low-Flow Frequency and Mean Annual Flow Statistics...............................................................4

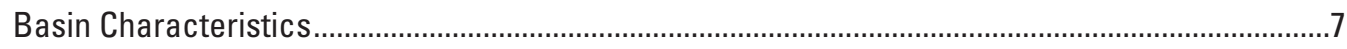

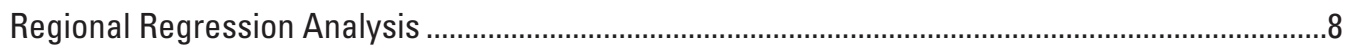

Development of Regional Regression Equations ..................................................................8

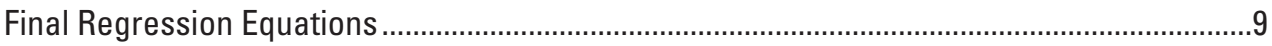

Accuracy and Limitations ................................................................................................ 11

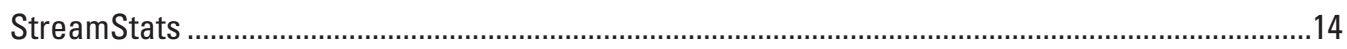

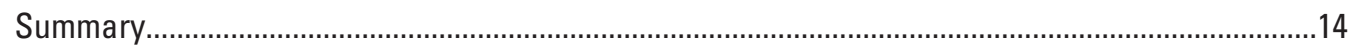

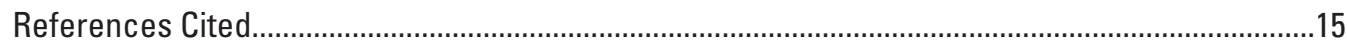

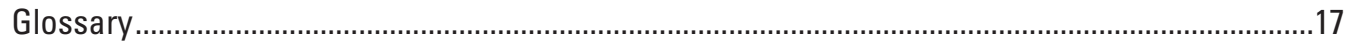

\section{Figure}

1. Map showing location of the study area, the ecoregions in the study area, and the streamgages that were considered for use in the regional regression analysis for north Georgia

\section{Tables}

1. Description of streamgages located in north Georgia and surrounding States that were evaluated for use in the regional regression analysis for north Georgia

2. Selected low-flow frequency and mean annual flow statistics compiled for 56 continuous-record streamgages in north Georgia and surrounding States that were evaluated for use in the low-flow frequency regression analysis for north Georgia, 2013.

3. Basin characteristics considered for use in the low-flow frequency regression analysis for north Georgia.

4. Selected low-flow frequency statistic and mean annual flow equations for ungaged streams in north Georgia

5. Values used to determine prediction intervals for the regression equations ..................12

6. Ranges of explanatory variables used to develop the regression equations for north Georgia. 


\section{Conversion Factors}

U.S. customary units to International System of Units

\begin{tabular}{|c|c|c|}
\hline Multiply & By & To obtain \\
\hline \multicolumn{3}{|c|}{ Length } \\
\hline inch (in.) & 2.54 & centimeter $(\mathrm{cm})$ \\
\hline inch (in.) & 25.4 & millimeter (mm) \\
\hline foot $(\mathrm{ft})$ & 0.3048 & meter $(\mathrm{m})$ \\
\hline \multicolumn{3}{|c|}{ Area } \\
\hline square mile $\left(\mathrm{mi}^{2}\right)$ & 259.0 & hectare (ha) \\
\hline square mile $\left(\mathrm{mi}^{2}\right)$ & 2.590 & square kilometer $\left(\mathrm{km}^{2}\right)$ \\
\hline \multicolumn{3}{|c|}{ Flow rate } \\
\hline cubic foot per second $\left(\mathrm{ft}^{3} / \mathrm{s}\right)$ & 0.02832 & cubic meter per second $\left(\mathrm{m}^{3} / \mathrm{s}\right)$ \\
\hline
\end{tabular}

Temperature in degrees Fahrenheit $\left({ }^{\circ} \mathrm{F}\right)$ may be converted to degrees Celsius $\left({ }^{\circ} \mathrm{C}\right)$ as follows:

$$
{ }^{\circ} \mathrm{C}=\left({ }^{\circ} \mathrm{F}-32\right) / 1.8 \text {. }
$$

\section{Datums}

Vertical coordinate information is referenced to the North American Vertical Datum of 1988 (NAVD 88).

Horizontal coordinate information is referenced to either the North American Datum of 1927 (NAD 27) or the North American Datum of 1983 (NAD 83).

Elevation, as used in this report, refers to distance above the vertical datum. 


\section{Abbreviations}

1010 minimum 1-day average streamflow with a 10-year recurrence interval

7010 minimum 7-day average streamflow with a 10-year recurrence interval

APS all possible subsets

DEM digital elevation model

DNR Georgia Department of Natural Resources

EPA U.S. Environmental Protection Agency

EPD Georgia Environmental Protection Division

GIS geographic information system

GAGES-II Geospatial Attributes of Gages for Evaluating Streamflow, version II, dataset

MSE mean square error

NWIS USGS National Water Information System

OLS ordinary least squares

SEE standard error of estimate

SWSTAT USGS Surface-Water Statistics computer program

USGS U.S. Geological Survey

VIF variance inflation factor 


\section{Acknowledgments}

The author wishes to thank the many local, State, and Federal agencies that have cooperated in the support of the operation and maintenance of the streamgages used in this study.

The author also wishes to thank the U.S. Geological Survey (USGS) staff for their dedicated work in collecting, processing, and storing the streamflow data necessary for the completion of this study. Lastly, the author wishes to thank USGS employee Jonathan Musser for geographic information system (GIS) support. 


\title{
Methods for Estimating Selected Low-Flow Frequency Statistics and Mean Annual Flow for Ungaged Locations on Streams in North Georgia
}

\author{
By Anthony J. Gotvald
}

\section{Abstract}

The U.S. Geological Survey, in cooperation with the Georgia Department of Natural Resources, Environmental Protection Division, developed regional regression equations for estimating selected low-flow frequency and mean annual flow statistics for ungaged streams in north Georgia that are not substantially affected by regulation, diversions, or urbanization. Selected low-flow frequency statistics and basin characteristics for 56 streamgage locations within north Georgia and 75 miles beyond the State's borders in Alabama, Tennessee, North Carolina, and South Carolina were combined to form the final dataset used in the regional regression analysis. Because some of the streamgages in the study recorded zero flow, the final regression equations were developed using weighted left-censored regression analysis to analyze the flow data in an unbiased manner, with weights based on the number of years of record. The set of equations includes the annual minimum 1- and 7-day average streamflow with the 10-year recurrence interval (referred to as 1Q10 and 7Q10), monthly 7Q10, and mean annual flow. The final regional regression equations are functions of drainage area, mean annual precipitation, and relief ratio for the selected lowflow frequency statistics and drainage area and mean annual precipitation for mean annual flow. The average standard error of estimate was 13.7 percent for the mean annual flow regression equation and ranged from 26.1 to 91.6 percent for the selected low-flow frequency equations.

The equations, which are based on data from streams with little to no flow alterations, can be used to provide estimates of the natural flows for selected ungaged stream locations in the area of Georgia north of the Fall Line. The regression equations are not to be used to estimate flows for streams that have been altered by the effects of major dams, surface-water withdrawals, groundwater withdrawals (pumping wells), diversions, or wastewater discharges. The regression equations should be used only for ungaged sites with drainage areas between 1.67 and 576 square miles, mean annual precipitation between 47.6 and 81.6 inches, and relief ratios between 0.146 and 0.607 ; these are the ranges of the explanatory variables used to develop the equations. An attempt was made to develop regional regression equations for the area of Georgia south of the Fall Line by using the same approach used during this study for north Georgia; however, the equations resulted with high average standard errors of estimates and poorly predicted flows below 0.5 cubic foot per second, which may be attributed to the karst topography common in that area.

The final regression equations developed from this study are planned to be incorporated into the U.S. Geological Survey StreamStats program. StreamStats is a Web-based geographic information system that provides users with access to an assortment of analytical tools useful for water-resources planning and management, and for engineering design applications, such as the design of bridges. The StreamStats program provides streamflow statistics and basin characteristics for U.S. Geological Survey streamgage locations and ungaged sites of interest. StreamStats also can compute basin characteristics and provide estimates of streamflow statistics for ungaged sites when users select the location of a site along any stream in Georgia.

\section{Introduction}

Reliable estimates of low-flow frequency statistics are essential for water-resources planning, management, and permitting to ensure that an adequate water supply exists for consumptive use, water-quality standards are met, recreation is feasible, and aquatic habitat is minimally impaired. Engineers, scientists, water-resource managers, and many others use lowflow frequency statistics for (1) establishing minimum flow requirements for streams and rivers, (2) quantifying base flows in streams and rivers, (3) wastewater discharge permitting, (4) water-supply planning and management, (5) protecting stream biota and ecosystems, and (6) evaluating time of travel and dilution of toxic spills (Ries, 2006). Recent droughts in the southeastern United States also have emphasized the need to better understand low-flow frequency statistics for sustained water supplies and ecological-flow requirements for the protection of aquatic resources in Georgia. 
Estimates of low-flow frequency statistics are needed not only at locations where streamflow, hereafter referred to as flow, is monitored but also for ungaged basins where flow is not recorded. Therefore, other methods, such as regionalization, may be used to estimate low-flow frequency statistics at ungaged sites. Regionalization uses regression analysis to develop equations that relate low-flow frequency information determined for a group of streamgages ${ }^{1}$ within a hydrologic region to various basin characteristics for the same streamgages. The resultant equations then can be used to estimate low-flow magnitude and frequency for ungaged stream locations within the hydrologic region.

The Georgia Environmental Protection Division (EPD) within the Georgia Department of Natural Resources (DNR) uses low-flow frequency statistics in its mission to provide the strategic information necessary to manage the State's water resources and to assess the amount of flow needed to maintain the ecological integrity of surface waters. The EPD also uses low-flow statistics in its mission to protect and enhance Georgia's surface-water and groundwater resources. The regression equations developed as part of this study by the U.S. Geological Survey (USGS), in cooperation with the Georgia EPD, can be used to estimate selected low-flow frequency and mean annual flow statistics for ungaged stream locations in north Georgia. The regression equations are planned to be incorporated into StreamStats, a Web-based geographic information system (GIS) tool developed by the USGS (Ries and others, 2008).

\section{Purpose and Scope}

The purpose of this report is to present methods for estimating low-flow frequency statistics for the annual minimum 1- and 7-day average flow with the 10-year recurrence interval (referred to as $1 \mathrm{Q} 10$ and 7Q10), monthly $7 \mathrm{Q} 10$, and mean annual flow for ungaged stream locations in north Georgia that are not substantially affected by regulation, diversions, or urbanization. The report describes (1) the streamgage and basin characteristics selection processes; (2) the methods used to develop regression equations that can be used to estimate the selected low-flow frequency statistics and mean annual flow; (3) the accuracy and limitations of the equations; and (4) the StreamStats Web application for automatically measuring required basin-characteristics data and solving the regression equations to quickly and easily estimate low-flow frequency statistics.

\section{Description of the Study Area}

The State of Georgia encompasses 59,425 square miles $\left(\mathrm{mi}^{2}\right)$ in the southeastern United States. Elevations range from sea level (referenced to the North American Vertical Datum of 1988) in coastal areas to 4,784 feet (ft) above sea level

\footnotetext{
${ }^{1}$ Terms shown in bold are defined in the glossary.
}

in northeast Georgia. Because of its proximity to the warm waters of the Gulf of Mexico and the Atlantic Ocean, most of Georgia has warm, humid summers and short, mild winters. In the northern part of the State, however, elevation becomes the more predominant influence with resulting cooler summers and colder, but not severe, winters. Average summer temperatures range from about 72 degrees Fahrenheit $\left({ }^{\circ} \mathrm{F}\right)$ in the northeastern mountains to nearly $82^{\circ} \mathrm{F}$ in parts of southern Georgia. Average winter temperatures range from $39^{\circ} \mathrm{F}$ in the north to about $55^{\circ} \mathrm{F}$ along the southern coast. Average annual precipitation ranges from 45 inches in central and east-central Georgia to 75 inches in the extreme northeastern corner of the State (National Oceanic and Atmospheric Administration, 2016).

The study area encompasses the area of Georgia north of the Fall line, which comprises about two-fifths of the State and incorporates four U.S. Environmental Protection Agency (EPA) level III ecoregions - Southwestern Appalachians, Ridge and Valley, Blue Ridge, and Piedmont (fig. 1; U.S. Environmental Protection Agency, 2016). The Fall Line, which is named for the steep fall of rivers as they cross this boundary, separates the higher-elevation Piedmont ecoregion from the low-lying Southeastern Plains ecoregion. The ecoregions represent areas of general similarity in ecosystems and in the type, quality, and quantity of environmental resources. The ecoregions provide a spatial framework for the research, assessment, management, and monitoring of ecosystems and ecosystem components. The ecoregions were determined from an analysis of the spatial patterns and the composition of biotic and abiotic phenomena that include geology, physiography, vegetation, climate, soils, land use, wildlife, and hydrology (Omernik, 1987).

The Southwestern Appalachians ecoregion is composed of open, low mountains. The eastern boundary of this ecoregion, along the more abrupt escarpment where it meets the Ridge and Valley ecoregion, is relatively smooth and only slightly notched by small, eastward-flowing streams. The Ridge and Valley ecoregion is composed of roughly parallel ridges and valleys of various widths, heights, and geologic materials. Springs and caves are relatively numerous, and present-day forests cover about 50 percent of the ecoregion. The Blue Ridge ecoregion varies from narrow ridges to hilly plateaus to more massive mountainous areas. The mostly forested slopes; high-gradient, cool, clear streams; and rugged terrain overlie primarily metamorphic rocks, with smaller areas of igneous and sedimentary geology (Omernik, 1987).

The Piedmont ecoregion is composed of a transitional area between the mostly mountainous regions of the Appalachians to the northwest and the relatively flat Coastal Plain to the southeast. The ecoregion is a complex mosaic of metamorphic and igneous rocks of Precambrian and Paleozoic age and contains moderately dissected, irregular plains and some hills. The soils tend to be finer textured in this ecoregion than in coastal plain regions to the south. Once largely cultivated, much of the ecoregion has reverted to pine and hardwood woodlands, with increasing conversion to urban and suburban land cover (Omernik, 1987). 

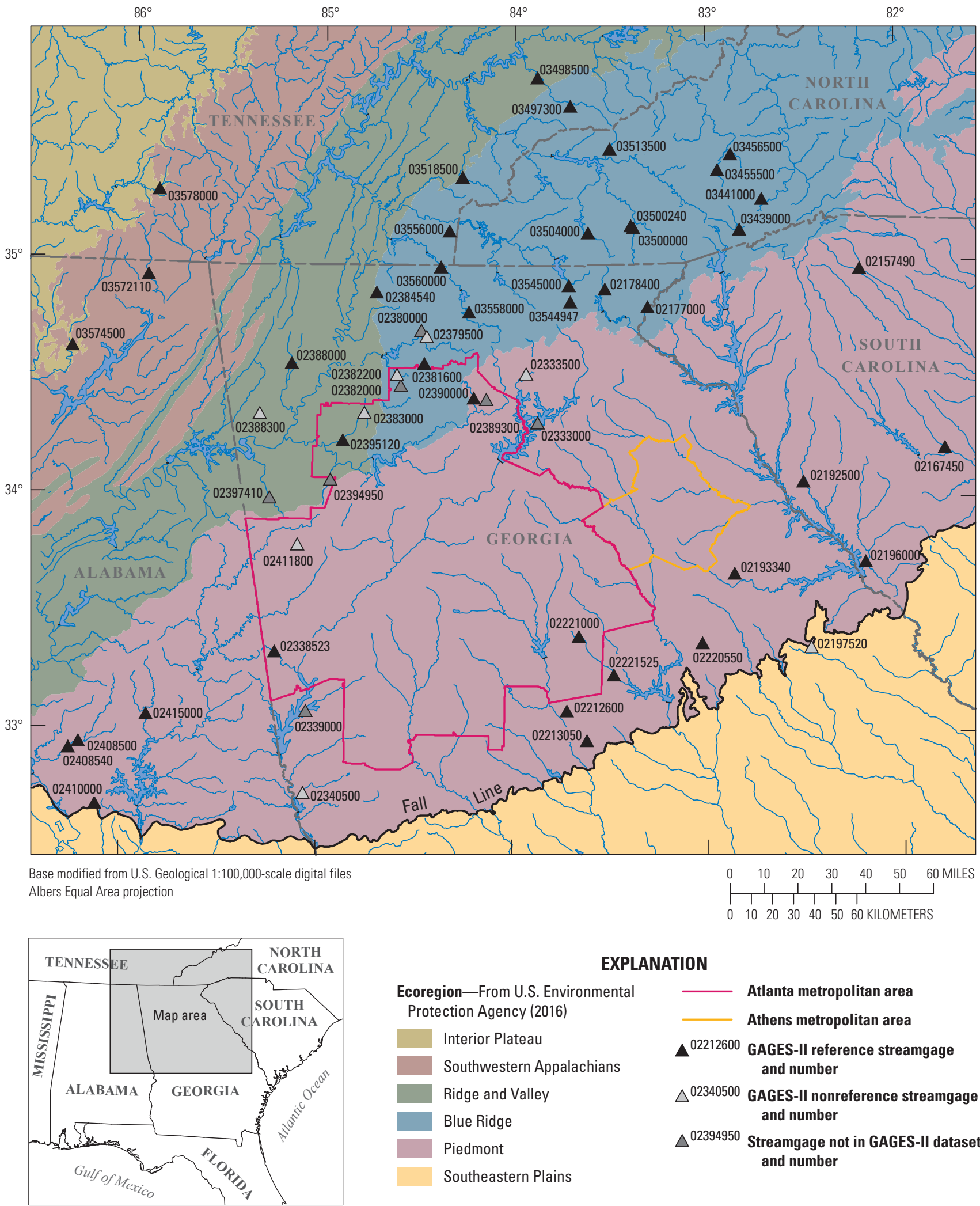

EXPLANATION

Ecoregion-From U.S. Environmental Protection Agency (2016)

Interior Plateau

Southwestern Appalachians

Ridge and Valley

Blue Ridge

Piedmont

Southeastern Plains
Atlanta metropolitan area

Athens metropolitan area

$\Delta{ }^{02212600}$ GAGES-II reference streamgage and number

$\triangle^{02340500}$ GAGES-II nonreference streamgage and number

$\triangle^{02394950}$ Streamgage not in GAGES-II dataset and number

Figure 1. Location of the study area, the ecoregions in the study area, and the streamgages that were considered for use in the regional regression analysis for north Georgia (Geospatial Attributes of Gages for Evaluating Streamflow, version II [GAGES-II]; Omernik, 1987). 


\section{Selection of Streamgages}

The streamgage selection process for this study started with the Geospatial Attributes of Gages for Evaluating Streamflow, version II (GAGES-II) dataset, which provides geospatial data and classifications for 9,322 streamgages maintained by the USGS (Falcone, 2011). The GAGES-II dataset consists only of streamgages that have 20 or more years of record since 1950 or are currently active (Falcone, 2011). The GAGES-II dataset was used to determine the streamgages with watersheds in the study area that are least disturbed by human influence. Streamgages with "nearnatural" flow conditions were identified in the GAGES-II dataset and classified as "reference" streamgages (Falcone, 2011). All reference streamgages in north Georgia having 10 or more years of record through climatic year 2013 were evaluated for possible use in the regional regression analysis, resulting in a total of 18 reference streamgages in Georgia that were determined as candidate streamgages for the regression analysis. Also, seven streamgages in Georgia that have 10 or more years of natural flows and that are not in the GAGES-II dataset were included as candidate streamgages for the regression analysis.

The GAGES-II dataset has a hydrologic "disturbance index" associated with each streamgage that is used to assess if the streamgage is a reference or nonreference streamgage. This index quantifies the human influence on the stream using variables, such as density of major dams, amount of water withdrawals, and percentage of channels in the watershed (Falcone, 2011). Streamgages in Georgia with a disturbance index below 20 were evaluated for flow alteration processes such as water withdrawals, diversions, flood control, and wastewater discharge. Sites in drainage basins with known flow-altered processes not substantial enough to clearly change the recorded daily mean flows for more than several days during each climatic year were included in the dataset. The change was assessed by visual inspection of the daily mean flows plotted on a graph. As a result, eight nonreference streamgages in north Georgia were included as candidate streamgages for the regression analysis for a total of 33 streamgages in Georgia.

Because the Atlanta and Athens metropolitan areas are within the study area, only a limited number of Georgia streamgages are considered to have "near-natural" flow (fig. 1). Thus, GAGES-II reference streamgages having 10 or more years of record through climatic year 2013 in Alabama, Tennessee, North Carolina, and South Carolina that are within 75 miles of the Georgia border were included as candidate streamgages for the regression analysis. This added 23 streamgages to the dataset (6 in Alabama, 5 in Tennessee, 8 in North Carolina, and 4 in South Carolina), resulting in a total of 56 candidate streamgages. Descriptive information for the candidate streamgages, including the USGS station number, station name, latitude, longitude, county, and drainage area, is provided in table 1 (at back of report, available for download at https://doi.org/10.3133/sir20175001); the 56 streamgage locations are shown in figure 1.

\section{Low-Flow Frequency and Mean Annual Flow Statistics}

For the 33 streamgages in Georgia that were considered for use in the regression analysis, the annual 1Q10 and $7 \mathrm{Q} 10$, monthly 7Q10, and mean annual flow statistics were obtained from Gotvald (2016). For the 23 streamgages in the surrounding States, the annual 1Q10 and 7Q10, monthly $7 \mathrm{Q} 10$, and mean annual flow statistics were computed for this study by using the same methods described in Gotvald (2016) to maintain consistency. The statistics for the 23 streamgages were computed using the daily mean flow data through the 2013 water year from the USGS National Water Information System (NWIS; U.S. Geological Survey, 2015) and Surface-Water Statistics (SWSTAT) version 5.0, a computer program developed by the USGS (Hutchison, 1975; Lumb and others, 1990; Flynn and others, 1995). The annual 1Q10 and $7 \mathrm{Q} 10$, monthly 7Q10, and mean annual flow statistics for the 56 streamgage locations that were considered in the regression analysis are presented in table 2 (available for download at https://doi.org/10.3133/sir20175001), and the periods of record used to compute the statistics are provided in table 1.

Some of the streamgages with shorter periods of record that were considered in the regression analysis indicate significant negative trends in the minimum 1-day and 7-day flows because the period of record ends during recent droughts that occurred in the study area (Gotvald, 2016). As noted by Lins and others (2010), hydrologic records of a few years to a few decades may indicate a trend in the data, but when viewed in the context of longer timeframes spanning decades to centuries, the short-term trends may be recognized as part of a much longer-term oscillation. The streamgages with significant negative trends were still considered for use in the regression analysis because the streamgages with longer-term records considered in the regression analysis did not indicate significant trends (Gotvald, 2016). 
Table 2. Selected low-flow frequency and mean annual flow statistics compiled for 56 continuous-record streamgages in north Georgia and surrounding States that were evaluated for use in the low-flow frequency regression analysis for north Georgia, 2013.

[USGS, U.S. Geological Survey; $\mathrm{ft}^{3} / \mathrm{s}$, cubic foot per second; 1Q10, minimum 1-day average streamflow with a 10-year recurrence interval; 7Q10, minimum 7-day average streamflow with a 10 -year recurrence interval]

\begin{tabular}{|c|c|c|c|c|c|c|c|c|c|c|c|c|c|c|c|}
\hline \multirow{3}{*}{$\begin{array}{l}\text { USGS } \\
\text { station } \\
\text { number }\end{array}$} & \multicolumn{15}{|c|}{ Streamflow $\left(\mathrm{ft}^{3} / \mathrm{s}\right)$} \\
\hline & \multicolumn{2}{|c|}{ Annual } & January & February & March & April & May & June & July & August & September & October & November & December & Mean \\
\hline & 1010 & 7010 & & & & & & & 7010 & & & & & & flow \\
\hline 02157490 & 0.21 & 0.33 & 11.2 & 11.7 & 13.3 & 9.64 & 7.11 & 2.80 & 1.56 & 0.55 & 0.92 & 3.50 & 5.06 & 7.14 & 20.1 \\
\hline 02167450 & 0.75 & 1.13 & 35.9 & 53.1 & 68.1 & 47.6 & 27.9 & 16.4 & 7.81 & 3.23 & 1.58 & 3.35 & 10.8 & 25.4 & 156 \\
\hline 02178400 & 33.1 & 35.0 & 81.6 & 98.4 & 111 & 111 & 87.4 & 64.5 & 50.9 & 40.9 & 37.2 & 37.6 & 43.0 & 62.0 & 181 \\
\hline 02192500 & 1.75 & 2.21 & 51.3 & 67.9 & 86.3 & 74.6 & 38.7 & 20.4 & 9.63 & 4.56 & 3.80 & 5.39 & 12.2 & 29.2 & 190 \\
\hline 02193340 & 0 & 0 & 1.87 & 3.86 & 6.47 & 4.79 & 1.91 & 0.86 & 0.20 & 0.04 & 0.04 & 0 & 0.44 & 1.01 & 23.0 \\
\hline 02196000 & 0.62 & 1.09 & 24.5 & 51.7 & 79.3 & 50.4 & 18.2 & 9.39 & 5.40 & 3.62 & 2.13 & 1.77 & 2.34 & 8.38 & 371 \\
\hline 02220550 & 0.05 & 0.06 & 2.54 & 4.38 & 4.95 & 4.98 & 2.68 & 1.49 & 0.78 & 0.33 & 0.13 & 0.09 & 0.87 & 1.63 & 14.6 \\
\hline 02221000 & 1.33 & 1.56 & 8.26 & 11.5 & 14.9 & 12.4 & 7.80 & 5.49 & 3.59 & 2.94 & 1.97 & 1.82 & 2.92 & 5.69 & 25.0 \\
\hline 02221525 & 1.03 & 1.65 & 38.5 & 58.1 & 76.6 & 53.9 & 22.6 & 8.36 & 3.92 & 2.73 & 3.65 & 4.19 & 10.6 & 22.7 & 147 \\
\hline 02333000 & 255 & 292 & 480 & 518 & 729 & 788 & 613 & 525 & 463 & 413 & 322 & 298 & 349 & 409 & 1180 \\
\hline 02333500 & 56.6 & 60.5 & 152 & 176 & 213 & 215 & 162 & 120 & 96.2 & 72.2 & 64.0 & 71.0 & 87.1 & 110 & 353 \\
\hline 02338523 & 0.84 & 1.05 & 5.68 & 7.53 & 12.4 & 10.4 & 6.01 & 3.24 & 2.46 & 1.21 & 1.32 & 1.77 & 3.03 & 4.60 & 19.9 \\
\hline 02339000 & 10.9 & 13.0 & 88.3 & 109 & 124 & 125 & 63.2 & 45.1 & 30.4 & 21.8 & 13.5 & 18.3 & 31.1 & 58.0 & 228 \\
\hline 02340500 & 6.65 & 7.51 & 27.9 & 34.6 & 45.4 & 45.0 & 28.2 & 19.8 & 16.6 & 10.6 & 7.98 & 9.60 & 12.0 & 18.7 & 81.6 \\
\hline 02383000 & 0.35 & 0.44 & 1.64 & 2.59 & 3.84 & 3.25 & 2.31 & 1.62 & 0.90 & 0.66 & 0.47 & 0.58 & 0.84 & 1.06 & 6.85 \\
\hline 02384540 & 0.24 & 0.30 & 4.69 & 6.68 & 7.48 & 5.96 & 2.96 & 1.49 & 0.87 & 0.43 & 0.34 & 0.50 & 1.11 & 2.66 & 17.5 \\
\hline 02388000 & 5.16 & 5.62 & 16.0 & 19.6 & 25.7 & 19.8 & 13.1 & 9.33 & 7.00 & 6.76 & 6.46 & 5.98 & 6.04 & 7.73 & 65.8 \\
\hline 02388300 & 0.83 & 0.91 & 4.7 & 6.97 & 7.57 & 5.38 & 2.75 & 1.98 & 1.22 & 1.09 & 1.05 & 1.20 & 1.56 & 1.85 & 25.2 \\
\hline 02389300 & 14.8 & 15.1 & 20.4 & 26.3 & 31.9 & 32.8 & 31.5 & 26.6 & 20.9 & 18.0 & 16.6 & 16.4 & 18.8 & 18.3 & 50.4 \\
\hline 02390000 & 34.3 & 37.1 & 119 & 94.76 & 125 & 140 & 103 & 71.4 & 61.9 & 41.8 & 39.5 & 43.7 & 53.3 & 63.3 & 199 \\
\hline
\end{tabular}


Table 2. Selected low-flow frequency and mean annual flow statistics compiled for 56 continuous-record streamgages in north Georgia and surrounding States that were evaluated for use in the low-flow frequency regression analysis for north Georgia, 2013.-Continued

[USGS, U.S. Geological Survey; fts/s, cubic foot per second; 1Q10, minimum 1-day average streamflow with a 10-year recurrence interval; 7Q10, minimum 7-day average streamflow with a 10 -year recurrence interval]

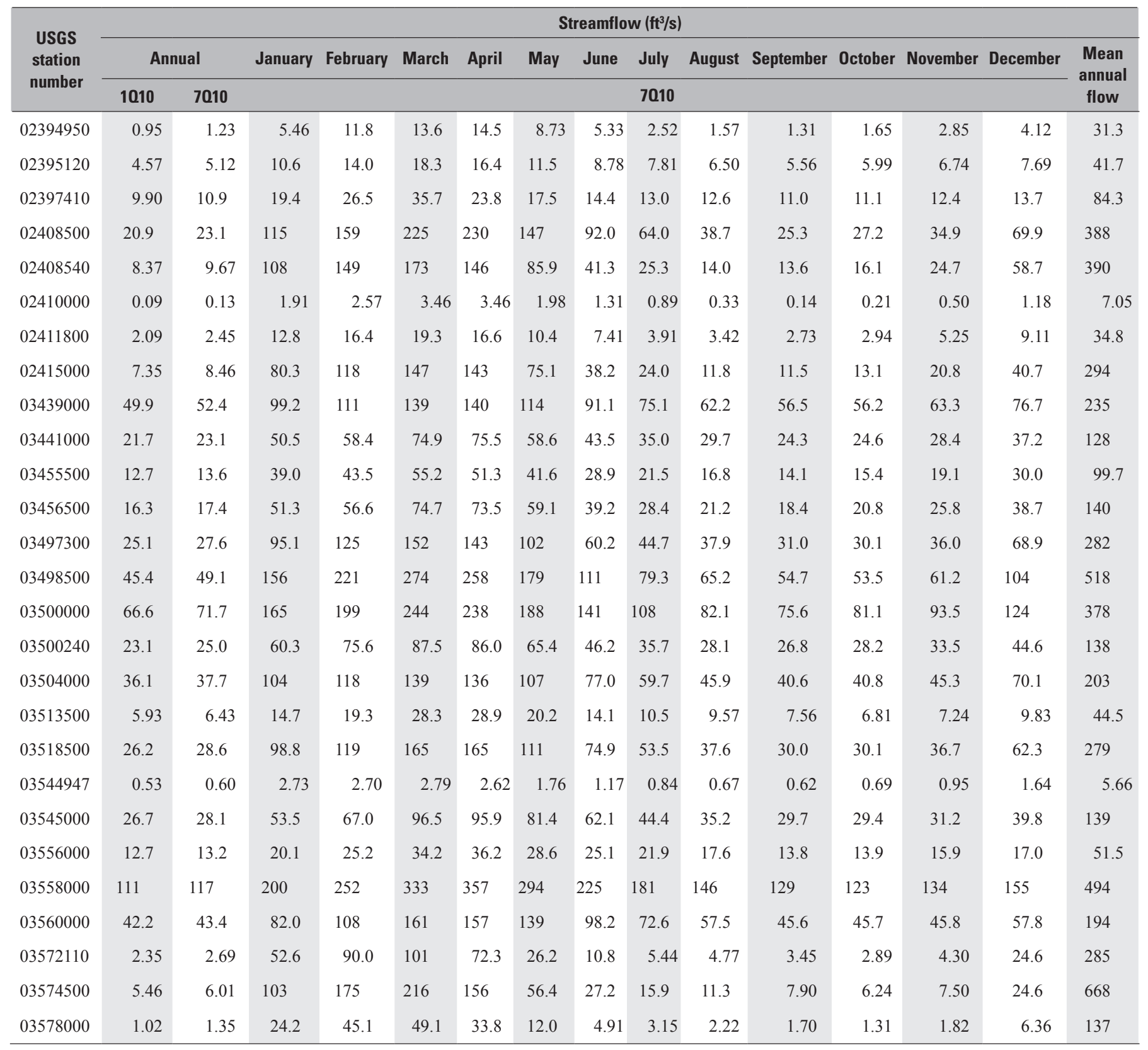




\section{Basin Characteristics}

The GAGES-II dataset includes several hundred basin characteristics compiled from national data sources, including environmental features and metrics of anthropogenic influence (Falcone, 2011). A subset of these basin characteristics was chosen as potential explanatory variables in the regional regression analysis using all-possible-subsets (APS) regression methods (Neter and others, 1985). Potential explanatory variables for inclusion in the regression analysis were based on several factors, including standard error of the estimate, Mallow's $C_{P}$ statistic, statistical significance of the explanatory variables, coefficient of determination $\left(R^{2}\right)$, the theoretical relation of the basin characteristics to low flows, and ease of computing the basin characteristics using geographic information system (GIS) technology. The use of GIS enables the automation of the basin-characteristic calculations and solution of the regional regression equations using StreamStats. Table 3 lists the 15 potential basin characteristics that were considered for use in the regional regression analysis.

The potential basin characteristics listed in table 3 were computed using the methods from the Georgia StreamStats application for the 33 streamgages in Georgia in order to maintain consistency when the final regression equations

Table 3. Basin characteristics considered for use in the low-flow frequency regression analysis for north Georgia.

[PRISM, Parameter-Elevation Regressions on Independent Slopes Model; NLCD, National Land Cover Database; STATSGO, State Soil Geographic (database)]

\begin{tabular}{|c|c|c|c|}
\hline Name & Description & Unit & Data source \\
\hline \multicolumn{4}{|c|}{ Physical measurements } \\
\hline DRNAREA & Drainage area of basin & Square miles & http://waterdata.usgs.gov/nwis/ \\
\hline PRECIP & Mean annual precipitation & Inches & $\begin{array}{l}\text { 800-meter resolution PRISM 1971-2000 } \\
\text { data (http://prism.nacse.org/) }\end{array}$ \\
\hline ELEV & Mean basin elevation & Feet & http://ned.usgs.gov/ \\
\hline ELEVMAX & Maximum basin elevation & Feet & http://ned.usgs.gov/ \\
\hline ELEVMIN & Minimum basin elevation & Feet & http://ned.usgs.gov/ \\
\hline RRMEAN & $\begin{array}{l}\text { Relief ratio ((ELEV-ELEVMIN)/ } \\
\quad(\text { ELEVMAX-ELEVMIN)) }\end{array}$ & Unitless & http://ned.usgs.gov/ \\
\hline \multicolumn{4}{|c|}{ Land use } \\
\hline LC06FOREST & Percentage of basin area covered by forest & Percent & 2006 NLCD (http://www.mrlc.gov) \\
\hline LC06SHRUB & Percentage of basin area covered by shrubs & Percent & 2006 NLCD (http://www.mrlc.gov) \\
\hline LC06PAST & Percentage of basin area covered by pasture & Percent & 2006 NLCD (http://www.mrlc.gov) \\
\hline \multicolumn{4}{|c|}{ Soils } \\
\hline STATSNO4AVE & $\begin{array}{l}\text { Average value of percentage by weight of } \\
\text { soil material less than } 3 \text { inches in size } \\
\text { and passing a no. } 4 \text { sieve }\end{array}$ & Percent & $\begin{array}{l}\text { STATSGO data (http://water.usgs.gov/GIS/ } \\
\text { metadata/usgswrd/XML/muid.xml) }\end{array}$ \\
\hline STATSNO10AVE & $\begin{array}{l}\text { Average value of percentage by weight of } \\
\text { soil material less than } 3 \text { inches in size } \\
\text { and passing a no. } 10 \text { sieve }\end{array}$ & Percent & $\begin{array}{l}\text { STATSGO data (http://water.usgs.gov/GIS/ } \\
\text { metadata/usgswrd/XML/muid.xml) }\end{array}$ \\
\hline STATSNO200AVE & $\begin{array}{l}\text { Average value of percentage by weight of } \\
\text { soil material less than } 3 \text { inches in size } \\
\text { and passing a no. } 200 \text { sieve }\end{array}$ & Percent & $\begin{array}{l}\text { STATSGO data (http://water.usgs.gov/GIS/ } \\
\text { metadata/usgswrd/XML/muid.xml) }\end{array}$ \\
\hline STATSSILT & Average value of silt content & Percent & $\begin{array}{l}\text { STATSGO data (http://water.usgs.gov/GIS/ } \\
\text { metadata/usgswrd/XML/muid.xml) }\end{array}$ \\
\hline STATSSAND & Average value of sand content & Percent & $\begin{array}{l}\text { STATSGO data (http://water.usgs.gov/GIS/ } \\
\text { metadata/usgswrd/XML/muid.xml) }\end{array}$ \\
\hline WTDEPAVE & $\begin{array}{l}\text { Average value of depth to seasonally } \\
\text { high water table }\end{array}$ & Inches & $\begin{array}{l}\text { STATSGO data (http://water.usgs.gov/GIS/ } \\
\text { metadata/usgswrd/XML/muid.xml) }\end{array}$ \\
\hline
\end{tabular}


are implemented in the Georgia StreamStats application. Currently (2016), StreamStats is not fully implemented for all the surrounding States, so the basin characteristics from the GAGES-II dataset were used for the surrounding States. To ensure that the GAGES-II basin characteristics are equivalent to the basin characteristics computed using the StreamStats methods, the StreamStats values were compared with the basin characteristics from the GAGES-II dataset for the 26 streamgages in Georgia that are in the GAGES-II dataset. The differences in the two sets of basin characteristics were within \pm 2.5 percent for all the basin characteristics with the exception of the maximum and minimum elevation, which had differences greater than \pm 2.5 percent for 3 of the 26 sites. The larger differences in the extreme elevation values likely result from a lower resolution digital elevation model (DEM) being used for the GAGES-II computations. The mean of the differences is within \pm 1 percent for all the basin characteristics, thus indicating that the basin characteristics from the GAGES-II dataset are comparable to values computed using the StreamStats methods.

A drainage area value is stored in the NWIS database for most streamgages maintained by the USGS. The drainage area in the NWIS database was compared to the drainage area computed using the StreamStats methods for the 33 streamgages in Georgia and the computed drainage area in the GAGES-II dataset for the 23 streamgages in the surrounding States. All the computed drainage areas were within \pm 2 percent of the NWIS drainage areas for the 33 streamgages in Georgia and were within \pm 3 percent for the 23 streamgages in the surrounding States. None of the drainage areas for the 33 Georgia streamgages were revised in the NWIS database on the basis of the USGS Office of Surface Water Technical Memorandum No. 12.07 (Lins, 2012), which suggests revisions be made in the database for differences that are more than 2 percent if the computed value is more accurate than the value in the NWIS database. Although 2 (USGS station numbers 02167450 and 03455500 ) of the 23 streamgages in the surrounding States had differences greater than 2 percent, the NWIS database values were not revised for the 2 stations because a lower resolution DEM had been used to delineate the watersheds. The drainage areas listed in table 1, which are from the NWIS database, are the drainage area values used in the regional regression analysis. Table 1 also lists the other 14 potential basin characteristics for the 56 streamgage locations that were considered for use in the regional regression analysis. The basin characteristics for the 33 Georgia streamgages are available in StreamStats (U.S. Geological Survey, 2016).

\section{Regional Regression Analysis}

Regional regression analyses were used to develop equations that estimate the annual 1Q10 and 7Q10, monthly 7Q10, and mean annual flow statistics at ungaged locations in north Georgia not substantially affected by regulation, diversions, or urbanization. The equations relate the statistics computed from flow records for streamgages to measured basin characteristics of the associated drainage basins. All 56 streamgages for which flood-frequency and basin characteristics had been determined were considered for use in the regression analysis (fig. 1; table 1).

\section{Development of Regional Regression Equations}

All-possible-subsets regression methods and ordinary least squares (OLS) regression techniques were used to evaluate candidate explanatory variables (table 3 ) and the need for additional hydrologic regions within the study area. Ordinary least squares regression analyses were performed using the 56 streamgages with various combinations of candidate explanatory variables on the basis of the APS regression results. Multicollinearity (correlation among the candidate explanatory variables) was assessed by the variance inflation factor $(V I F)$. All response variables and some explanatory variables were transformed to logarithms (base 10) prior to the regression analyses to (1) obtain linear relations between response and explanatory variables and (2) achieve equal variance about the regression line. Regression residuals were plotted at the centroid of the respective drainage area to determine geographical patterns of bias. On the basis of the residual plots, there is no indication of a geographic bias of the regression residuals.

The need to divide the study area into separate hydrologic regions was further investigated using the qualitative indicator variable approach described by Griffis and Stedinger (2007). This approach tests the differences among the intercept in a regression model for separate regions by including qualitative indicator variables for each region in the model. For this study, qualitative indicator variables of " 1 " or " 0 " for each ecoregion were included as explanatory variables in the regression equations. If 75 percent or more of the drainage basin of a streamgage was within a specific ecoregion, a value of " 1 " was used for the qualitative variable for that ecoregion; otherwise, a " 0 " was used to indicate the basin is not within that ecoregion. None of the qualitative indicator explanatory variables for the ecoregions were found to be statistically significant for a probability value ( $p$-value) $\leq 0.05$, indicating that the intercepts for each ecoregion are not significantly different and confirming that the study area did not need to be further divided into additional hydrologic regions. 


\section{Final Regression Equations}

Because some streams in this study had values of zero for the selected low-flow frequency statistics, special regression techniques were required to analyze these statistics in an unbiased manner. Estimates of zero flow computed from observed flow commonly are treated as left-censored data (Kroll and Stedinger, 1996; Kroll and Vogel, 2002), and the use of multiple-linear regression is not recommended for censored data (Helsel and Hirsch, 2002). For this study, weighted left-censored regression was used for the final regression analyses, with weights based on the number of years of record (Lorenz, 2014; Ziegeweid and others, 2015). With left-censored regression, a threshold value is imposed on the dataset that censors low (left) values below the threshold. Both the censored and uncensored values are used in a left-censored regression. When datasets do not contain censored values, weighted left-censored regression provides the same results as weighted least squares regression (Helsel and Hirsch, 2002).

Weighted left-censored regression was used to analyze flow data collected at 56 streamgages. Various combinations of explanatory variables determined in exploratory analyses were evaluated. Because of the uncertainty in measuring low flows and estimating low-flow frequency statistics less than 0.1 cubic foot per second $\left(\mathrm{ft}^{3} / \mathrm{s}\right)$, the censoring threshold used to develop the left-censored regression equations was set at $0.1 \mathrm{ft}^{3} / \mathrm{s}$. The combination of independent explanatory variables selected for inclusion in the final regression equations did not have multicollinearity, were statistically significant at the 0.05 level, and provided the lowest standard error of estimate for the flow statistics.

Multiple performance metrics were used to identify streamgages with potential issues that were used in the final regression equations. Residuals randomly distributed around zero are preferred. The leverage metric is used to measure how unusual the values of independent variables at one streamgage are compared to the values of the same variables at all other streamgages (Helsel and Hirsch, 2002). The influence metric indicates whether the data at a streamgage have a large influence on the estimated regression parameter values (Helsel and Hirsch, 2002). A streamgage may have a large leverage metric, indicating that independent variables associated with the streamgage are substantially different from independent variables associated with all other streamgages; however, the same streamgage may not have a large influence on the regression parameters. Conversely, a streamgage with a large influence on the regression parameters may not have a large leverage metric. Measurement or typographic errors in reported values of some independent variables may produce large leverage or influence metrics, and streamgages with such errors may need to be excluded. None of the streamgages used in the final regression analysis indicated high influence; however, two streamgages (USGS station numbers 02196000 and 03544947) were identified in this study as having large leverage. These two streamgages were not excluded because no known errors were associated with the basin characteristic data, and a reasonable hydrologic justification for excluding the data could not be identified.

For the selected low-flow statistics, the combination of drainage area (DRNAREA), mean annual precipitation (PRECIP), and relief ratio (RRMEAN) reduced the standard error considerably more than any other combination of explanatory variables, so these three explanatory variables were used in the final regression equations. For mean annual flow, DRNAREA and PRECIP are used in the final equation because RRMEAN was not found to be statistically significant for a probability value ( $\mathrm{p}$-value) $\leq 0.05$, and the addition of a third variable did not reduce the standard error by more than 1 percent. Residuals from the weighted left-censored analyses were plotted on a map of the study area to verify that geographical biases were not present. One hydrologic region was used for the entire study area. The final regional regression equations for the selected low-flow frequency and mean annual flow statistics are given in table 4. For the selected low-flow frequency equations in table 4 , the estimated flow statistic decreases as RRMEAN increases. RRMEAN is a measure of the relief in the drainage basin; therefore, a higher RRMEAN value indicates higher relief in the basin, which increases direct runoff and decreases base flow. 
Table 4. Selected low-flow frequency statistic and mean annual flow equations for ungaged streams in north Georgia.

[SEE, standard error of estimate, in percent; number censored, number of streamflow values less than or equal to 0.1 cubic foot per second; M1D10Y, annual 1-day low flow for a recurrence interval of 10 years, in cubic feet per second; M7D10Y, annual 7-day low flow for a recurrence interval of 10 years, in cubic feet per second; M7D10Y01, January 7-day low flow for a recurrence interval of 10 years, in cubic feet per second; M7D10Y02, February 7-day low flow for a recurrence interval of 10 years, in cubic feet per second; M7D10Y03, March 7-day low flow for a recurrence interval of 10 years, in cubic feet per second; M7D10Y04, April 7-day low flow for a recurrence interval of 10 years, in cubic feet per second; M7D10Y05, May 7-day low flow for a recurrence interval of 10 years, in cubic feet per second; M7D10Y06, June 7-day low flow for a recurrence interval of 10 years, in cubic feet per second; M7D10Y07, July 7-day low flow for a recurrence interval of 10 years, in cubic feet per second; M7D10Y08, August 7-day low flow for a recurrence interval of 10 years, in cubic feet per second; M7D10Y09, September 7-day low flow for a recurrence interval of 10 years, in cubic feet per second; M7D10Y10, October 7-day low flow for a recurrence interval of 10 years, in cubic feet per second; M7D10Y11, November 7-day low flow for a recurrence interval of 10 years, in cubic feet per second; and M7D10Y12, December 7-day low flow for a recurrence interval of 10 years, in cubic feet per second; QA, mean annual flow, in cubic feet per second; DRNAREA, drainage area, in square miles; PRECIP, mean annual precipitation, in inches; RRMEAN, relief ratio]

\begin{tabular}{|c|c|c|c|}
\hline Statistic & Regression equation & $\begin{array}{c}\text { SEE } \\
\text { (percent) }\end{array}$ & $\begin{array}{l}\text { Number } \\
\text { censored }\end{array}$ \\
\hline M1D10Y & $\left(4.42 \times 10^{-16}\right)(\text { DRNAREA })^{0.914}(\text { PRECIP })^{8.62}\left(2.12 \times 10^{-3}\right)^{\text {RRMEAN }}$ & 91.6 & 4 \\
\hline M7D10Y & $\left(2.11 \times 10^{-15}\right)(\text { DRNAREA })^{0.907}(\text { PRECIP })^{8.25}\left(3.11 \times 10^{-3}\right)^{\text {RRMEAN }}$ & 86.4 & 3 \\
\hline M7D10Y01 & $\left(1.60 \times 10^{-8}\right)(\text { DRNAREA })^{0.936}(\text { PRECIP })^{4.42}\left(1.94 \times 10^{-1}\right)^{\text {RRMEAN }}$ & 34.5 & 0 \\
\hline M7D10Y02 & $\left(1.43 \times 10^{-7}\right)(\text { DRNAREA })^{0.955}(\text { PRECIP })^{3.89}\left(3.54 \times 10^{-1}\right)^{\text {RRMEAN }}$ & 26.6 & 0 \\
\hline M7D10Y03 & $\left(2.09 \times 10^{-7}\right)(\text { DRNAREA })^{0.974}(\text { PRECIP })^{3.83}\left(3.69 \times 10^{-1}\right)^{\text {RRMEAN }}$ & 26.1 & 0 \\
\hline M7D10Y04 & $\left(3.20 \times 10^{-8}\right)(\text { DRNAREA })^{0.962}(\text { PRECIP })^{4.33}\left(1.77 \times 10^{-1}\right)^{\text {RRMEAN }}$ & 32.8 & 0 \\
\hline M7D10Y05 & $\left(1.01 \times 10^{-9}\right)(\text { DRNAREA })^{0.920}(\text { PRECIP })^{5.21}\left(4.86 \times 10^{-2}\right)^{\text {RRMEAN }}$ & 46.6 & 0 \\
\hline M7D10Y06 & $\left(8.43 \times 10^{-11}\right)(\text { DRNAREA })^{0.901}(\text { PRECIP })^{5.80}\left(2.01 \times 10^{-2}\right)^{\text {RRMEAN }}$ & 60.0 & 0 \\
\hline M7D10Y07 & $\left(1.69 \times 10^{-12}\right)(\text { DRNAREA })^{0.912}(\text { PRECIP })^{6.70}\left(9.72 \times 10^{-3}\right)^{\text {RRMEAN }}$ & 73.2 & 0 \\
\hline M7D10Y08 & $\left(4.95 \times 10^{-14}\right)(\text { DRNAREA })^{0.933}(\text { PRECIP })^{7.47}\left(7.79 \times 10^{-3}\right)^{\text {RRMEAN }}$ & 87.9 & 2 \\
\hline M7D10Y09 & $\left(2.37 \times 10^{-14}\right)(\text { DRNAREA })^{0.938}(\text { PRECIP })^{7.63}\left(5.27 \times 10^{-3}\right)^{\text {RRMEAN }}$ & 81.9 & 1 \\
\hline M7D10Y10 & $\left(1.46 \times 10^{-13}\right)(\text { DRNAREA })^{0.892}(\text { PRECIP })^{7.30}\left(3.08 \times 10^{-3}\right)^{\text {RRMEAN }}$ & 83.0 & 2 \\
\hline M7D10Y11 & $\left(5.12 \times 10^{-10}\right)(\text { DRNAREA })^{0.790}(\text { PRECIP })^{5.48}\left(5.03 \times 10^{-3}\right)^{\text {RRMEAN }}$ & 63.9 & 0 \\
\hline M7D10Y12 & $\left(2.93 \times 10^{-9}\right)(\text { DRNAREA })^{0.874}(\text { PRECIP })^{4.90}\left(4.45 \times 10^{-2}\right)^{\text {RRMEAN }}$ & 49.4 & 0 \\
\hline QA & $\left(9.20 \times 10^{-6}\right)(\text { DRNAREA })^{0.993}(\text { PRECIP })^{2.97}$ & 13.7 & 0 \\
\hline
\end{tabular}




\section{Accuracy and Limitations}

The average standard error of estimate (SEE), in percent, for the regression equations is given in table 4. Average SEE is a measure of the average uncertainty of predictions made with a regression equation on the basis of all streamgage data used to develop the equations. Users of the regression equations may, however, be interested in a measure of uncertainty for a flow estimate at a particular ungaged stream location as opposed to the average uncertainty based on all streamgage data. One such measure of uncertainty at a particular ungaged location is the confidence interval of a prediction, or prediction interval. Prediction interval is the range in values of an estimated response variable over which the true value of the response variable occurs with some stated probability. For example, the 90-percent prediction interval for an estimated flow value means that there is a 90-percent probability that the true flow value lies within that interval. The USGS StreamStats Web-based GIS tool uses the 90-percent prediction interval estimates as part of the computation of low-flow frequency estimates for ungaged stream sites. Tasker and Driver (1988) determined that a $100(1-\alpha)$ prediction interval for a flow statistic estimated at an ungaged site from a regression equation can be computed as follows:

$$
Q / C<Q<C Q
$$

where

$Q \quad$ is the flow characteristic for the ungaged site; and

$C$ is computed as:

$$
C=10^{t_{(\alpha / 2, n-p)}} S E_{P, i},
$$

where

$$
\begin{gathered}
t_{(\alpha / 2, n-p)} \quad \text { is the critical value from the student's } \\
\text { t-distribution at a particular alpha-level } \\
\text { divided by } 2(\alpha / 2) \text {, and degrees of freedom } \\
(n-p) \text { and is equal to } 1.68 \text { for an }(\alpha) \text { of } \\
\text { 0.10, which corresponds to a prediction } \\
\text { interval of } 90 \text { percent; and } \\
\text { is the standard error of prediction for site } i \text { and } \\
\text { is computed for a weighted left-censored } \\
\text { regression analysis as }
\end{gathered}
$$

$$
S E_{P, i}=\left[M S E+\mathbf{X}_{i} \mathbf{U} \mathbf{X}_{i}^{T}\right]^{0.5},
$$

where

$$
\begin{gathered}
M S E \quad \text { is the mean square error; } \\
\mathbf{X}_{i} \quad \text { is a row vector of the explanatory } \\
\text { variables for site } i \text {, augmented by } \\
\text { a } 1 \text { as the first element; } \\
\mathbf{U} \quad \text { is the covariance matrix for the regression } \\
\text { coefficients; and } \\
\mathbf{X}_{i}^{T} \quad \text { is the transpose of } \mathbf{X}_{i} \text { (Ludwig and } \\
\quad \text { Tasker, 1993). }
\end{gathered}
$$

The values for $M S E$ and $\mathbf{U}$ are presented in table 5 (available for download at https://doi.org/10.3133/sir20175001).

The procedures required to obtain the prediction intervals for annual $1 \mathrm{Q} 10$ and 7Q10, monthly 7Q10, and mean annual flow estimates are explained in the following example computation of the annual 7Q10 flow for a hypothetical ungaged site on Indian Creek near Big City, Georgia. The results are rounded to three significant figures.

1. Obtain the drainage area and mean annual precipitation for the ungaged site (DRNAREA $=5.00 \mathrm{mi}^{2}$, $P R E C I P=65.0$ inches, $R R M E A N=0.200)$;

2. Compute annual $7 \mathrm{Q} 10$ flow using the equation in table 4 (annual $Q_{7010}=\left(2.11 \times 10^{-15}\right) \cdot 5.00^{0.907} \cdot 65.0^{8.25}$ $\left.\cdot\left(3.11 \times 10^{-3}\right)^{0.200}=2.59 \mathrm{ft}^{3} / \mathrm{s}\right)$;

3. Determine the $\mathbf{X}_{i}$ vector $\left(\mathbf{X}_{i}=\{1, \log (5.00)\right.$, $\log (65.0)\}, 0.200)$;

4. Compute the standard error of prediction using equation 3 with $M S E$ and $\mathbf{U}$ for the $7 \mathrm{Q} 10$ flow from table 5; $S E_{P, i}=(0.1053+0.0177)^{0.5}=0.3507$;

5. Compute $C$ using equation $2 ; C=10^{(1.68 \cdot 0.3507)}=3.883$; and

6. Compute the 90-percent prediction interval using equation $1 ;(2.59 / 3.883)<Q_{7 Q 10}<(2.59 \cdot 2.883)$ or $0.667 \mathrm{ft}^{3} / \mathrm{s}<Q_{7 Q 10}<10.1 \mathrm{ft}^{3} / \mathrm{s}$.

Solution: The annual 7Q10 flow estimated for the hypothetical ungaged site on Indian Creek is $2.59 \mathrm{ft}^{3} / \mathrm{s}$ with the 90-percent prediction interval between 0.667 and $10.1 \mathrm{ft}^{3} / \mathrm{s}$. 
Table 5. Values used to determine prediction intervals for the regression equations.

[MSE, the mean square error used in equation 3; $\mathrm{U}$, the covariance matrix used in equation 3; M1D10Y, annual 1-day low flow for a recurrence interval of 10 years, in cubic feet per second; M7D10Y, annual 7-day low flow for a recurrence interval of 10 years, in cubic feet per second; M7D10Y01, January 7-day low flow for a recurrence interval of 10 years, in cubic feet per second; M7D10Y02, February 7-day low flow for a recurrence interval of 10 years, in cubic feet per second; M7D10Y03, March 7-day low flow for a recurrence interval of 10 years, in cubic feet per second; M7D10Y04, April 7-day low flow for a recurrence interval of 10 years, in cubic feet per second; M7D10Y05, May 7-day low flow for a recurrence interval of 10 years, in cubic feet per second; M7D10Y06, June 7-day low flow for a recurrence interval of 10 years, in cubic feet per second; M7D10Y07, July 7-day low flow for a recurrence interval of 10 years, in cubic feet per second; M7D10Y08, August 7-day low flow for a recurrence interval of 10 years, in cubic feet per second; M7D10Y09, September 7-day low flow for a recurrence interval of 10 years, in cubic feet per second; M7D10Y10, October 7-day low flow for a recurrence interval of 10 years, in cubic feet per second; M7D10Y11, November 7-day low flow for a recurrence interval of 10 years, in cubic feet per second; and M7D10Y12, December 7-day low flow for a recurrence interval of 10 years, in cubic feet per second; QA, mean annual flow, in cubic feet per second]

\begin{tabular}{|c|c|c|c|c|c|}
\hline \multirow{2}{*}{$\begin{array}{l}\text { Statistic } \\
\text { M1D10Y }\end{array}$} & \multirow{2}{*}{$\begin{array}{r}\text { MSE } \\
0.1149\end{array}$} & \multicolumn{4}{|c|}{$\mathbf{U}$} \\
\hline & & $1.96 \mathrm{E}+00$ & $-3.74 \mathrm{E}-02$ & $-9.95 \mathrm{E}-01$ & $-2.85 \mathrm{E}-01$ \\
\hline & & $-3.74 \mathrm{E}-02$ & $9.23 \mathrm{E}-03$ & $1.06 \mathrm{E}-02$ & $2.70 \mathrm{E}-03$ \\
\hline & & $-9.95 \mathrm{E}-01$ & $1.06 \mathrm{E}-02$ & $5.19 \mathrm{E}-01$ & $1.18 \mathrm{E}-01$ \\
\hline & & $-2.85 \mathrm{E}-01$ & $2.70 \mathrm{E}-03$ & $1.18 \mathrm{E}-01$ & $1.91 \mathrm{E}-01$ \\
\hline \multirow[t]{4}{*}{ M7D10Y } & 0.1053 & $1.78 \mathrm{E}+00$ & $-3.21 \mathrm{E}-02$ & $-9.04 \mathrm{E}-01$ & $-2.64 \mathrm{E}-01$ \\
\hline & & $-3.21 \mathrm{E}-02$ & $8.15 \mathrm{E}-03$ & $8.84 \mathrm{E}-03$ & $2.88 \mathrm{E}-03$ \\
\hline & & $-9.04 \mathrm{E}-01$ & $8.84 \mathrm{E}-03$ & $4.72 \mathrm{E}-01$ & $1.09 \mathrm{E}-01$ \\
\hline & & $-2.64 \mathrm{E}-01$ & $2.88 \mathrm{E}-03$ & $1.09 \mathrm{E}-01$ & $1.74 \mathrm{E}-01$ \\
\hline \multirow[t]{4}{*}{ M7D10Y01 } & 0.0213 & $3.53 \mathrm{E}-01$ & $-6.20 \mathrm{E}-03$ & $-1.79 \mathrm{E}-01$ & $-5.35 \mathrm{E}-02$ \\
\hline & & $-6.20 \mathrm{E}-03$ & $1.63 \mathrm{E}-03$ & $1.64 \mathrm{E}-03$ & $5.92 \mathrm{E}-04$ \\
\hline & & $-1.79 \mathrm{E}-01$ & $1.64 \mathrm{E}-03$ & $9.35 \mathrm{E}-02$ & $2.21 \mathrm{E}-02$ \\
\hline & & $-5.35 \mathrm{E}-02$ & $5.92 \mathrm{E}-04$ & $2.21 \mathrm{E}-02$ & $3.51 \mathrm{E}-02$ \\
\hline \multirow[t]{4}{*}{ M7D10Y02 } & 0.0129 & $2.14 \mathrm{E}-01$ & $-3.77 \mathrm{E}-03$ & $-1.09 \mathrm{E}-01$ & $-3.25 \mathrm{E}-02$ \\
\hline & & $-3.77 \mathrm{E}-03$ & $9.90 \mathrm{E}-04$ & $9.97 \mathrm{E}-04$ & $3.59 \mathrm{E}-04$ \\
\hline & & $-1.09 \mathrm{E}-01$ & $9.97 \mathrm{E}-04$ & $5.68 \mathrm{E}-02$ & $1.34 \mathrm{E}-02$ \\
\hline & & $-3.25 \mathrm{E}-02$ & $3.59 \mathrm{E}-04$ & $1.34 \mathrm{E}-02$ & $2.13 \mathrm{E}-02$ \\
\hline \multirow[t]{4}{*}{ M7D10Y03 } & 0.0124 & $2.06 \mathrm{E}-01$ & $-3.62 \mathrm{E}-03$ & $-1.05 \mathrm{E}-01$ & $-3.12 \mathrm{E}-02$ \\
\hline & & $-3.62 \mathrm{E}-03$ & $9.53 \mathrm{E}-04$ & $9.60 \mathrm{E}-04$ & $3.46 \mathrm{E}-04$ \\
\hline & & $-1.05 \mathrm{E}-01$ & $9.60 \mathrm{E}-04$ & $5.46 \mathrm{E}-02$ & $1.29 \mathrm{E}-02$ \\
\hline & & $-3.12 \mathrm{E}-02$ & $3.46 \mathrm{E}-04$ & $1.29 \mathrm{E}-02$ & $2.05 \mathrm{E}-02$ \\
\hline \multirow[t]{4}{*}{ M7D10Y04 } & 0.0193 & $3.20 \mathrm{E}-01$ & $-5.63 \mathrm{E}-03$ & $-1.62 \mathrm{E}-01$ & $-4.85 \mathrm{E}-02$ \\
\hline & & $-5.63 \mathrm{E}-03$ & $1.48 \mathrm{E}-03$ & $1.49 \mathrm{E}-03$ & $5.37 \mathrm{E}-04$ \\
\hline & & $-1.62 \mathrm{E}-01$ & $1.49 \mathrm{E}-03$ & $8.48 \mathrm{E}-02$ & $2.01 \mathrm{E}-02$ \\
\hline & & $-4.85 \mathrm{E}-02$ & $5.37 \mathrm{E}-04$ & $2.01 \mathrm{E}-02$ & $3.18 \mathrm{E}-02$ \\
\hline \multirow[t]{4}{*}{ M7D10Y05 } & 0.0370 & $6.15 \mathrm{E}-01$ & $-1.08 \mathrm{E}-02$ & $-3.12 \mathrm{E}-01$ & $-9.32 \mathrm{E}-02$ \\
\hline & & $-1.08 \mathrm{E}-02$ & $2.84 \mathrm{E}-03$ & $2.86 \mathrm{E}-03$ & $1.03 \mathrm{E}-03$ \\
\hline & & $-3.12 \mathrm{E}-01$ & $2.86 \mathrm{E}-03$ & $1.63 \mathrm{E}-01$ & $3.86 \mathrm{E}-02$ \\
\hline & & $-9.32 \mathrm{E}-02$ & $1.03 \mathrm{E}-03$ & $3.86 \mathrm{E}-02$ & $6.12 \mathrm{E}-02$ \\
\hline \multirow[t]{4}{*}{ M7D10Y06 } & 0.0579 & $9.62 \mathrm{E}-01$ & $-1.69 \mathrm{E}-02$ & $-4.88 \mathrm{E}-01$ & $-1.46 \mathrm{E}-01$ \\
\hline & & $-1.69 \mathrm{E}-02$ & $4.45 \mathrm{E}-03$ & $4.48 \mathrm{E}-03$ & $1.61 \mathrm{E}-03$ \\
\hline & & $-4.88 \mathrm{E}-01$ & $4.48 \mathrm{E}-03$ & $2.55 \mathrm{E}-01$ & $6.04 \mathrm{E}-02$ \\
\hline & & $-1.46 \mathrm{E}-01$ & $1.61 \mathrm{E}-03$ & $6.04 \mathrm{E}-02$ & $9.57 \mathrm{E}-02$ \\
\hline
\end{tabular}


Table 5. Values used to determine prediction intervals for the regression equations.-Continued

[MSE, the mean square error used in equation 3; $\mathrm{U}$, the covariance matrix used in equation 3; M1D10Y, annual 1-day low flow for a recurrence interval of 10 years, in cubic feet per second; M7D10Y, annual 7-day low flow for a recurrence interval of 10 years, in cubic feet per second; M7D10Y01, January 7-day low flow for a recurrence interval of 10 years, in cubic feet per second; M7D10Y02, February 7-day low flow for a recurrence interval of 10 years, in cubic feet per second; M7D10Y03, March 7-day low flow for a recurrence interval of 10 years, in cubic feet per second; M7D10Y04, April 7-day low flow for a recurrence interval of 10 years, in cubic feet per second; M7D10Y05, May 7-day low flow for a recurrence interval of 10 years, in cubic feet per second; M7D10Y06, June 7-day low flow for a recurrence interval of 10 years, in cubic feet per second; M7D10Y07, July 7-day low flow for a recurrence interval of 10 years, in cubic feet per second; M7D10Y08, August 7-day low flow for a recurrence interval of 10 years, in cubic feet per second; M7D10Y09, September 7-day low flow for a recurrence interval of 10 years, in cubic feet per second; M7D10Y10, October 7-day low flow for a recurrence interval of 10 years, in cubic feet per second; M7D10Y11, November 7-day low flow for a recurrence interval of 10 years, in cubic feet per second; and M7D10Y12, December 7-day low flow for a recurrence interval of 10 years, in cubic feet per second; QA, mean annual flow, in cubic feet per second]

\begin{tabular}{|c|c|c|c|c|c|}
\hline \multirow{2}{*}{$\begin{array}{r}\text { Statistic } \\
\text { M7D10Y07 }\end{array}$} & \multirow{2}{*}{$\begin{array}{r}\text { MSE } \\
0.0809\end{array}$} & \multicolumn{4}{|c|}{$\mathbf{U}$} \\
\hline & & $1.34 \mathrm{E}+00$ & $-2.36 \mathrm{E}-02$ & $-6.81 \mathrm{E}-01$ & $-2.04 \mathrm{E}-01$ \\
\hline & & $-2.36 \mathrm{E}-02$ & $6.21 \mathrm{E}-03$ & $6.25 \mathrm{E}-03$ & $2.25 \mathrm{E}-03$ \\
\hline & & $-6.81 \mathrm{E}-01$ & $6.25 \mathrm{E}-03$ & $3.56 \mathrm{E}-01$ & $8.43 \mathrm{E}-02$ \\
\hline & & $-2.04 \mathrm{E}-01$ & $2.25 \mathrm{E}-03$ & $8.43 \mathrm{E}-02$ & $1.34 \mathrm{E}-01$ \\
\hline \multirow[t]{4}{*}{ M7D10Y08 } & 0.1079 & $1.80 \mathrm{E}+00$ & $-3.17 \mathrm{E}-02$ & $-9.14 \mathrm{E}-01$ & $-2.71 \mathrm{E}-01$ \\
\hline & & $-3.17 \mathrm{E}-02$ & $8.29 \mathrm{E}-03$ & $8.46 \mathrm{E}-03$ & $2.97 \mathrm{E}-03$ \\
\hline & & $-9.14 \mathrm{E}-01$ & $8.46 \mathrm{E}-03$ & $4.77 \mathrm{E}-01$ & $1.12 \mathrm{E}-01$ \\
\hline & & $-2.71 \mathrm{E}-01$ & $2.97 \mathrm{E}-03$ & $1.12 \mathrm{E}-01$ & $1.78 \mathrm{E}-01$ \\
\hline \multirow[t]{4}{*}{ M7D10Y09 } & 0.0968 & $1.61 \mathrm{E}+00$ & $-2.84 \mathrm{E}-02$ & $-8.18 \mathrm{E}-01$ & $-2.43 \mathrm{E}-01$ \\
\hline & & $-2.84 \mathrm{E}-02$ & $7.44 \mathrm{E}-03$ & $7.58 \mathrm{E}-03$ & $2.66 \mathrm{E}-03$ \\
\hline & & $-8.18 \mathrm{E}-01$ & $7.58 \mathrm{E}-03$ & $4.27 \mathrm{E}-01$ & $1.00 \mathrm{E}-01$ \\
\hline & & $-2.43 \mathrm{E}-01$ & $2.66 \mathrm{E}-03$ & $1.00 \mathrm{E}-01$ & $1.60 \mathrm{E}-01$ \\
\hline \multirow[t]{4}{*}{ M7D10Y10 } & 0.0988 & $1.66 \mathrm{E}+00$ & $-2.97 \mathrm{E}-02$ & $-8.40 \mathrm{E}-01$ & $-2.48 \mathrm{E}-01$ \\
\hline & & $-2.97 \mathrm{E}-02$ & $7.63 \mathrm{E}-03$ & $8.03 \mathrm{E}-03$ & $2.72 \mathrm{E}-03$ \\
\hline & & $-8.40 \mathrm{E}-01$ & $8.03 \mathrm{E}-03$ & $4.39 \mathrm{E}-01$ & $1.03 \mathrm{E}-01$ \\
\hline & & $-2.48 \mathrm{E}-01$ & $2.72 \mathrm{E}-03$ & $1.03 \mathrm{E}-01$ & $1.63 \mathrm{E}-01$ \\
\hline \multirow[t]{4}{*}{ M7D10Y11 } & 0.0646 & $1.07 \mathrm{E}+00$ & $-1.88 \mathrm{E}-02$ & $-5.44 \mathrm{E}-01$ & $-1.62 \mathrm{E}-01$ \\
\hline & & $-1.88 \mathrm{E}-02$ & $4.95 \mathrm{E}-03$ & $4.99 \mathrm{E}-03$ & $1.80 \mathrm{E}-03$ \\
\hline & & $-5.44 \mathrm{E}-01$ & $4.99 \mathrm{E}-03$ & $2.84 \mathrm{E}-01$ & $6.73 \mathrm{E}-02$ \\
\hline & & $-1.62 \mathrm{E}-01$ & $1.80 \mathrm{E}-03$ & $6.73 \mathrm{E}-02$ & $1.07 \mathrm{E}-01$ \\
\hline \multirow[t]{4}{*}{ M7D10Y12 } & 0.0411 & $6.83 \mathrm{E}-01$ & $-1.20 \mathrm{E}-02$ & $-3.47 \mathrm{E}-01$ & $-1.04 \mathrm{E}-01$ \\
\hline & & $-1.20 \mathrm{E}-02$ & $3.16 \mathrm{E}-03$ & $3.18 \mathrm{E}-03$ & $1.15 \mathrm{E}-03$ \\
\hline & & $-3.47 \mathrm{E}-01$ & $3.18 \mathrm{E}-03$ & $1.81 \mathrm{E}-01$ & $4.29 \mathrm{E}-02$ \\
\hline & & $-1.04 \mathrm{E}-01$ & $1.15 \mathrm{E}-03$ & $4.29 \mathrm{E}-02$ & $6.80 \mathrm{E}-02$ \\
\hline \multirow[t]{3}{*}{ QA } & 0.0035 & $4.48 \mathrm{E}-02$ & $-8.76 \mathrm{E}-04$ & $-2.40 \mathrm{E}-02$ & \\
\hline & & $-8.76 \mathrm{E}-04$ & $2.68 \mathrm{E}-04$ & $2.10 \mathrm{E}-04$ & \\
\hline & & $-2.40 \mathrm{E}-02$ & $2.10 \mathrm{E}-04$ & $1.31 \mathrm{E}-02$ & \\
\hline
\end{tabular}


The following limitations need to be recognized when using the final regional regression equations:

1. Applying the equations to sites on streams having explanatory variables outside the ranges of those used in this study may result in standard errors that are considerably greater than those indicated by the standard error of estimates percentages listed in table 4. The ranges of explanatory variables used to develop the regional regression equations are given in table 6. The geometric mean is included to represent the most typical values for the range of the data.

2. The methods are not appropriate (or applicable) for streams where the flow is substantially affected by regulation, diversion, or urbanization.

3. The basin-characteristic calculations at ungaged locations should be computed using the same GIS datasets and calculation methods used in this study. The USGS StreamStats Web-based GIS tool (Ries and others, 2008; U.S. Geological Survey, 2016) includes the same GIS data layers and calculation methods used to develop the regression equations in this study.

4. Special attention must be given to censored values and the number of significant figures used. Because of the uncertainty in measuring and estimating flows less than $0.1 \mathrm{ft}^{3} / \mathrm{s}$, the censoring threshold used to develop the leftcensored regression equations was set at $0.1 \mathrm{ft}^{3} / \mathrm{s}$. Thus, any regression estimates that are $0.1 \mathrm{ft}^{3} / \mathrm{s}$ or less should be reported as less than $0.1 \mathrm{ft}^{3} / \mathrm{s}$.

5. Regional regression equations developed for the area of Georgia south of the Fall Line poorly predicted flows below $0.5 \mathrm{ft}^{3} / \mathrm{s}$ and produced high SEE values; therefore, equations presented in this report are applicable only to the area of Georgia north of the Fall Line. Poor predictive abilities south of the Fall Line may be caused by karst topography in the area. In karst topography, low flows could be substantially affected by gains from large springs and by losses from sinkholes (Eash and Barnes, 2012).

Table 6. Ranges of explanatory variables used to develop the regression equations for north Georgia.

$\left[\mathrm{mi}^{2}\right.$, square miles]

\begin{tabular}{lccc}
\hline Basin characteristic & Minimum & Maximum & $\begin{array}{c}\text { Geometric } \\
\text { mean }\end{array}$ \\
\hline $\begin{array}{l}\text { Drainage area }\left(\mathrm{mi}^{2}\right) \\
\begin{array}{c}\text { Mean annual precipi- } \\
\text { tation (inches) }\end{array}\end{array}$ & 1.67 & 576 & 58.0 \\
\begin{tabular}{l} 
Relief ratio (unitless) \\
\hline
\end{tabular} & 0.146 & 0.607 & 60.3 \\
\hline
\end{tabular}

\section{StreamStats}

StreamStats is a Web-based GIS that provides users with access to an assortment of analytical tools that are useful for water-resources planning and management, and for engineering design applications (Ries and others, 2008). StreamStats allows users to easily obtain flow statistics, basin characteristics, and other information for user-selected sites on streams. StreamStats users can choose locations of interest from an interactive map and obtain information for those locations. If a user selects the location of a USGS streamgage, the user will be provided with a list of previously published information for the station. If a user selects a location where no data are available (an ungaged site), StreamStats will delineate the drainage-basin boundary, measure basin characteristics, and estimate flow statistics with prediction intervals for the site. Ries and others (2008) provide a detailed description of the application. Although designed to eventually be a national application, StreamStats is being implemented on a state-by-state basis, typically through cooperative funding agreements between the USGS and local partners.

Complete instructions for using StreamStats are provided through links on the StreamStats Web site at http://water.usgs.gov/ osw/streamstats/index.html. The Web site also provides links to (1) information about general limitations of the application, (2) other State applications, (3) user instructions, (4) definitions of terms, (5) answers to frequently asked questions, (6) downloadable presentations and other technical information about the application, and (7) contact information. Use of the regression equations developed in this study to estimate the annual 1Q10 and 7Q10, monthly 7Q10, and annual mean flow statistics will be implemented through incorporation into the USGS StreamStats Web-based GIS tool.

\section{Summary}

This report presents methods for estimating selected low-flow frequency and mean annual flow statistics at ungaged stream locations in the area of Georgia north of the Fall Line. Weighted left-censored regression was used to develop a set of regional regression equations for estimating the annual 1Q10 and 7Q10, monthly 7Q10, and mean annual flow statistics. Low-flow frequency and mean annual flow statistics and basin characteristics for 56 streamgage locations within north Georgia and 75 miles beyond the State's borders in Alabama, Tennessee, North Carolina, and South Carolina were combined to form the final dataset used in the regional regression analysis. Fifteen basin characteristics were considered for use as explanatory variables in the regression analysis. The final equations are functions of drainage area, mean annual precipitation, and relief ratio for the low-flow frequency statistics and drainage area, and mean annual precipitation for 
the mean annual flow. The average standard errors of estimate was 13.7 percent for the mean annual flow regression equation and ranged from 26.1 to 91.6 percent for the selected low-flow frequency equations. Methods also are provided to compute the 90-percent prediction intervals for the estimates at a particular ungaged stream location of interest.

The regression equations in this study, which are based on data from streams with little to no flow alterations, will provide an estimate of the natural flows for a selected ungaged stream location in the study area. The regression equations do not estimate flows for streams that have been altered by the effects of dams, surface-water withdrawals, groundwater withdrawals (pumping wells), diversions, or wastewater discharges. The regression equations should be used only for ungaged sites with drainage areas between 1.67 and 576 square miles, mean annual precipitation between 47.6 and 81.6 inches, and relief ratios between 0.146 and 0.607 ; these are the ranges of the explanatory variables used to develop the equations. An attempt was made to develop regional regression equations for the area of Georgia south of the Fall Line by using the same approach used in this study for north Georgia; however, the equations resulted in high average standard errors of estimates and poorly predicted flows below 0.5 cubic foot per second, likely because of karst topography in the area.

The regression equations developed in this study, as well as the 90-percent prediction intervals of the estimates, are planned to be incorporated into the USGS StreamStats program. The StreamStats program is a Web-based application that provides flow statistics and basin characteristics for USGS streamgages and ungaged sites of interest. StreamStats can also compute basin characteristics and provide estimates of flow statistics for ungaged stream locations when users select the location of a site along any stream in Georgia.

\section{References Cited}

Eash, D.A., and Barnes, K.K., 2012, Methods for estimating selected low-flow frequency statistics and harmonic mean flows for streams in Iowa: U.S. Geological Survey Scientific Investigations Report 2012-5171, 99 p., accessed July 7, 2016, at https://pubs.usgs.gov/sir/2012/5171/.

Falcone, J.A., 2011, GAGES-II-Geospatial attributes of gages for evaluation streamflow: U.S. Geological Survey [digital spatial dataset], accessed July 7, 2016, at https://pubs.er.usgs.gov/publication/70046617.

Flynn, K.M., Hummel, P.R., Lumb, A.M., and Kittle, J.L., Jr., 1995, User's manual for ANNIE, Version 2, A computer program for interactive hydrologic data management: U.S. Geological Survey Water-Resources Investigations Report 95-4085, 211 p. [Also available at https://pubs. er.usgs.gov/publication/wri954085.]
Gotvald, A.J., 2016, Selected low-flow frequency statistics for continuous-record streamgages in Georgia, 2013: U.S. Geological Survey Scientific Investigations Report 2016-5037, 20 p., accessed July 7, 2016, at https://doi.org/10.3133/ sir20165037.

Griffis, V.W., and Stedinger, J.R., 2007, The use of GLS regression in regional hydrologic analyses: Journal of Hydrology, v. 344, p. 82-95.

Helsel, D.R., and Hirsch, R.M., 2002, Statistical methods in water resources: U.S. Geological Survey Techniques of Water-Resources Investigations, book 4, chap. A3, 522 p., accessed July 7, 2015, at https://pubs.usgs.gov/twri/ twri4a3/.

Hutchison, N.E., comp., 1975 (revised 1984), WATSTORE user's guide, Volume 1, National Water Data Storage and Retrieval System: U.S. Geological Survey Open-File Report 75-426 [variously paged].

Kroll, C.N., and Stedinger, J.R., 1996, Estimation of moments and quantiles using censored data: Water Resources Research, v. 32, no. 4, p. 1005-1012, accessed July 7, 2016, at https://doi.org/10.1029/95WR03294.

Kroll, C.N., and Vogel, R.M., 2002, Probability distribution of low streamflow series in the United States: Journal of Hydrologic Engineering, v. 7, no. 2, p. 137-146., accessed July 7, 2016, at https://doi.org/10.1061/(ASCE)10840699(2002)7:2(137).

Lins, Katherine, 2012, Guidance on determination and revision of watershed drainage areas: U.S. Geological Survey Office of Surface Water Technical Memorandum No. 12.07 accessed July 13, 2016, at http://water.usgs.gov/admin/ memo/SW/sw12.07.html.

Lins, H.F., Hirsch, R.M., and Kiang, Julie, 2010, WaterThe Nation's fundamental climate issue-A white paper on the U.S. Geological Survey role and capabilities: U.S. Geological Survey Circular 1347, 9 p., accessed July 27, 2015, at http://pubs.usgs.gov/circ/1347/.

Lorenz, D.L., 2014, smwrQW-R functions to support water-quality data analysis for statistical methods in water resources: Geological Survey R Archive Network, accessed May 5, 2016, at https://github.com/USGS-R/smwrQW.

Ludwig, A.H., and Tasker, G.D., 1993, Regionalization of lowflow characteristics of Arkansas streams: U.S. Geological Survey Water-Resources Investigations Report 93-4013, 19 p. [Also available at https://pubs.er.usgs.gov/publication/ wri934013.] 
Lumb, A.M., Kittle, J.L., Jr., and Flynn, K.M., 1990, Users manual for ANNIE, a computer program for interactive hydrologic analyses and data management: U.S. Geological Survey Water-Resources Investigations Report 89-4080, 236 p. [Also available at https://pubs.usgs.gov/ wri/1989/4080/report.pdf.]

National Oceanic and Atmospheric Administration, 2016, Climate of Georgia: National Oceanic and Atmospheric Administration, National Centers for Environmental Information Web site, accessed July 7, 2016, at http://www.ncdc. noaa.gov/climatenormals/clim60/states/Clim_GA_01.pdf.

Neter, John, Wasserman, William, and Kutner, M.H., 1985, Applied linear statistical models: Homewood, Ill., Richard D. Irwin, Inc., 1,127 p.

Omernik, J.M., 1987, Ecoregions of the conterminous United States: Annals of the Association of American Geographers, v. 77, no. 1, p. 118-125, scale 1:7,500,000.

Ries, K.G., III, 2006, Selected streamflow statistics for streamgaging stations in northeastern Maryland, 2006: U.S. Geological Survey Open-File Report 2006-1335, 16 p., accessed July 7, 2016, at https://pubs.usgs.gov/ of/2006/1335/.

Ries, K.G., III, Guthrie, J.G., Rea, A.H., Steeves, P.A., and Stewart, D.W., 2008, StreamStats-A water resources Web application: U.S. Geological Survey Fact Sheet 2008-3067, 6 p., accessed July 7, 2016, at https://pubs.usgs.gov/ fs $/ 2008 / 3067 /$.
Tasker, G.D., and Driver, N.E., 1988, Nationwide regression models for predicting urban runoff water quality at unmonitored sites: Water Resources Bulletin, v. 24, no. 5, p. 1091-1101.

U.S. Environmental Protection Agency, 2016, Ecoregions of the United States: U.S. Environmental Protection Agency Web site, accessed July 7, 2016, at http://www.epa.gov/ eco-research/ecoregions.

U.S. Geological Survey, 2015, National Water Information System-Web interface, accessed April 3, 2015, at https://doi.org/10.5066/F7P55KJN.

U.S. Geological Survey, 2016, USGS StreamStats, accessed July 13, 2016, at http://streamstats.usgs.gov.

Ziegeweid, J.R., Lorenz, D.L., Sanocki, C.A., and Czuba, C.R., 2015, Methods for estimating flow-duration curve and low-flow frequency statistics for ungaged locations on small streams in Minnesota: U.S. Geological Survey Scientific Investigations Report 2015-5170, 23 p., accessed July 7, 2016, at https://doi.org/10.3133/sir20155170. 


\section{Glossary}

climatic year The annual period from April 1 through March 31 used by the U.S. Geological Survey (USGS) for lowflow analyses at USGS continuous-record streamgages. A climatic year is designated by the year in which the period begins. For example, the 2011 climatic year is April 1, 2011, to March 31, 2012. The year begins and ends during the period of typically increased streamflow so that all streamflow during a single dry season are included in annual values for that year.

drainage area The drainage area of a stream at a specified location is the area, measured in a horizontal plane, which is enclosed by a drainage divide.

record Unit value or daily mean streamflow data that are collected continuously from streamgage locations, electronically stored, published, and archived according to U.S. Geological Survey protocols.

recurrence interval As applied to low-flow statistics, the recurrence interval (sometimes called the return period) is based on the probability that the given event will be equal to or less than the estimated value in any given year. Thus, for the 7Q10, there is a 0.10 or 10 -percent probability that the annual minimum 7-day average flow in any 1 year will be less than the estimated 7Q10 value. relief ratio Dimensionless elevation ratio, calculated as the difference between mean and minimum elevation within the drainage basin divided by the difference in the maximum and minimum elevation within the drainage basin.

streamgage A site on a stream where continuous records of gage height are collected and for which streamflow records are computed.

water year The annual period from October 1 through September 30 that is used by the U.S. Geological Survey for the collection and processing of streamflow records. The water year is designated by the year in which the period ends. For example, the 2012 water year is October 1, 2011, to

September 30, 2012. 
Table 1. Description of streamgages located in north Georgia and surrounding States that were evaluated for use in the regional regression analysis for north Georgia.

[USGS, U.S. Geological Survey; ’ degree; ', minute; ", second. Datum: NAD 27, North American Datum of 1927; NAD 83, North American Datum of 1983. Units: $\mathrm{mi}^{2}$, square mile; in., inch; ft, foot. Variables: DRNAREA, drainage area of basin; PRECIP, mean annual precipitation; ELEV, mean basin elevation, ELEVMAX, maximum basin elevation; ELEVMIN, minimum basin elevation; RRMEAN, relief ratio; LC06FOREST, percentage of basin area covered by forest; LC06SHRUB, percentage of basin area covered by shrub; LC06PAST, percentage of basin area covered by pasture; STASNO4AVE, Average value of percentage by weight of soil material less than 3 inches in size and passing a no. 4 sieve; STASNO10AVE, Average value of percentage by weight of soil material less than 3 inches in size and passing a no. 10 sieve; STASNO200AVE, Average value of percentage by weight of soil material less than 3 inches in size and passing a no. 200 sieve; STATSSILT, average percentage of silt content; STATSSILT, average percentage of sand content; WTDEPAVE, average value of depth to seasonally high water table]

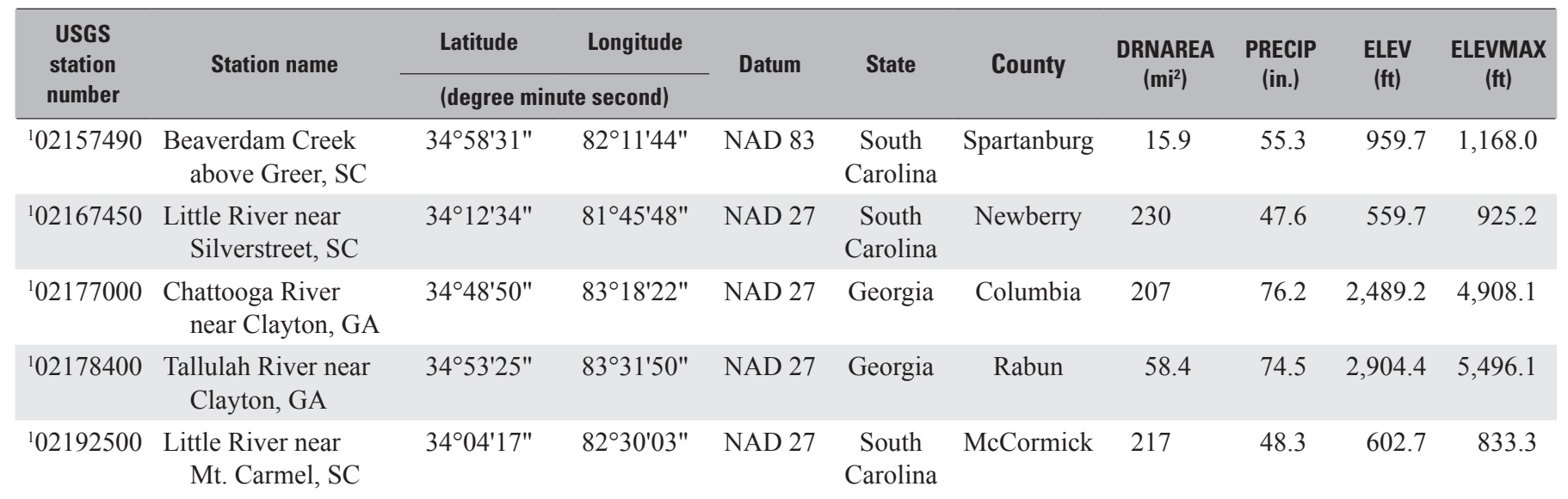

\begin{tabular}{|c|c|c|c|c|c|c|c|c|c|c|}
\hline${ }^{1} 02193340$ & $\begin{array}{l}\text { Kettle Creek near } \\
\text { Washington, GA }\end{array}$ & $33^{\circ} 40^{\prime} 57^{\prime \prime}$ & $82^{\circ} 51^{\prime 2} 29^{\prime \prime}$ & NAD 27 & Georgia & Wilkes & 33.9 & 48.3 & 565.5 & 703.4 \\
\hline${ }^{1} 02196000$ & $\begin{array}{l}\text { Stevens Creek near } \\
\text { Modoc, SC }\end{array}$ & $33^{\circ} 43^{\prime} 45^{\prime \prime}$ & $82^{\circ} 10^{\prime} 55^{\prime \prime}$ & NAD 27 & $\begin{array}{c}\text { South } \\
\text { Carolina }\end{array}$ & Edgefield & 545 & 48.0 & 465.4 & 669.3 \\
\hline
\end{tabular}

\begin{tabular}{|c|c|c|c|c|c|c|c|c|c|c|}
\hline${ }^{2} 02197520$ & $\begin{array}{l}\text { Brier Creek near } \\
\text { Thomson, GA }\end{array}$ & $33^{\circ} 22^{\prime} 06^{\prime \prime}$ & $82^{\circ} 28^{\prime} 06^{\prime \prime}$ & NAD 27 & Georgia & Mcduffie & 55.6 & 49.3 & 472.6 & 611.0 \\
\hline${ }^{1} 02212600$ & $\begin{array}{l}\text { Falling Creek near } \\
\text { Juliette, GA }\end{array}$ & $33^{\circ} 05^{\prime} 59^{\prime \prime}$ & $83^{\circ} 43^{\prime} 25^{\prime \prime}$ & NAD 27 & Georgia & Jones & 72.2 & 48.1 & 525.3 & 722.4 \\
\hline${ }^{1} 02213050$ & $\begin{array}{l}\text { Walnut Creek near } \\
\text { Gray, GA }\end{array}$ & $32^{\circ} 58^{\prime} 20^{\prime \prime}$ & $83^{\circ} 37^{\prime} 08^{\prime \prime}$ & NAD 27 & Georgia & Jones & 31.3 & 47.6 & 520.8 & 680.3 \\
\hline${ }^{1} 02220550$ & $\begin{array}{l}\text { Whitten Creek near } \\
\text { Sparta, GA }\end{array}$ & $33^{\circ} 23^{\prime} 12^{\prime \prime}$ & $83^{\circ} 01^{\prime} 34^{\prime \prime}$ & NAD 27 & Georgia & Hancock & 16.6 & 47.8 & 547.4 & 744.2 \\
\hline${ }^{1} 02221000$ & $\begin{array}{l}\text { Murder Creek near } \\
\text { Monticello, GA }\end{array}$ & $33^{\circ} 24^{\prime} 56^{\prime \prime}$ & $83^{\circ} 39^{\prime} 43^{\prime \prime}$ & NAD 27 & Georgia & Jasper & 23.3 & 48.8 & 652.2 & 805.3 \\
\hline${ }^{1} 02221525$ & $\begin{array}{l}\text { Murder Creek below } \\
\text { Eatonton, GA }\end{array}$ & $33^{\circ} 15^{\prime} 08^{\prime \prime}$ & $83^{\circ} 28^{\prime} 53^{\prime \prime}$ & NAD 27 & Georgia & Putnam & 190 & 48.5 & 579.4 & 805.3 \\
\hline${ }^{3} 02333000$ & $\begin{array}{l}\text { Chattahoochee } \\
\text { River near } \\
\text { Gainesville, GA }\end{array}$ & $34^{\circ} 19^{\prime} 17^{\prime \prime}$ & $83^{\circ} 52^{\prime} 46^{\prime \prime}$ & NAD 27 & Georgia & Hall & 576 & 64.6 & $1,556.5$ & $4,411.7$ \\
\hline
\end{tabular}


Table 1. Description of streamgages located in north Georgia and surrounding States that were evaluated for use in the regional regression analysis for north Georgia.-Continued

[USGS, U.S. Geological Survey; ’ , degree; ', minute; ", second. Datum: NAD 27, North American Datum of 1927; NAD 83, North American Datum of 1983. Units: $\mathrm{mi}^{2}$, square mile; in., inch; ft, foot. Variables: DRNAREA, drainage area of basin; PRECIP, mean annual precipitation; ELEV, mean basin elevation, ELEVMAX, maximum basin elevation; ELEVMIN, minimum basin elevation; RRMEAN, relief ratio; LC06FOREST, percentage of basin area covered by forest; LC06SHRUB, percentage of basin area covered by shrub; LC06PAST, percentage of basin area covered by pasture; STASNO4AVE, Average value of percentage by weight of soil material less than 3 inches in size and passing a no. 4 sieve; STASNO10AVE, Average value of percentage by weight of soil material less than 3 inches in size and passing a no. 10 sieve; STASNO200AVE, Average value of percentage by weight of soil material less than 3 inches in size and passing a no. 200 sieve; STATSSILT, average percentage of silt content; STATSSILT, average percentage of sand content; WTDEPAVE, average value of depth to seasonally high water table]

\begin{tabular}{|c|c|c|c|c|c|c|c|c|c|c|c|}
\hline $\begin{array}{l}\text { ELEVMIN } \\
\text { (ft) }\end{array}$ & $\begin{array}{l}\text { RRMEAN } \\
\text { (unitless) }\end{array}$ & $\begin{array}{l}\text { LCO6FOREST } \\
\text { (percent) }\end{array}$ & $\begin{array}{c}\text { LCO6SHRUB } \\
\text { (percent) }\end{array}$ & $\begin{array}{l}\text { LC06PAST } \\
\text { (percent) }\end{array}$ & $\begin{array}{c}\text { STATS- } \\
\text { NO4AVE } \\
\text { (percent) }\end{array}$ & $\begin{array}{c}\text { STATS- } \\
\text { N010AVE } \\
\text { (percent) }\end{array}$ & $\begin{array}{l}\text { STATSNO- } \\
\text { 200AVE } \\
\text { (percent) }\end{array}$ & $\begin{array}{c}\text { STATSSILT } \\
\text { (percent) }\end{array}$ & $\begin{array}{c}\text { STATSSAND } \\
\text { (percent) }\end{array}$ & $\begin{array}{l}\text { WTDE- } \\
\text { PAVE } \\
\text { (in.) }\end{array}$ & $\begin{array}{l}\text { Period of record } \\
\text { used in analysis }\end{array}$ \\
\hline 823.5 & 0.396 & 43.7 & 0.4 & 30.4 & 96.0 & 93.9 & 66.3 & 29.8 & 29.4 & 5.7 & $\begin{array}{c}\text { March 7, 2002- } \\
\text { September 30, } 2013\end{array}$ \\
\hline 367.5 & 0.345 & 59.8 & 2.7 & 17.0 & 94.9 & 92.1 & 61.5 & 29.8 & 33.3 & 5.6 & $\begin{array}{c}\text { March 30, 1990- } \\
\text { September 30, } 2013\end{array}$ \\
\hline $1,872.0$ & 0.285 & 94.6 & 0.8 & 1.9 & 91.3 & 86.6 & 47.3 & 35.6 & 45.4 & 5.9 & $\begin{array}{c}\text { July } 15,1964- \\
\text { September } 30,2013\end{array}$ \\
\hline 387.1 & 0.483 & 51.1 & 2.5 & 25.1 & 95.8 & 93.3 & 63.3 & 29.7 & 32.2 & 5.6 & $\begin{array}{c}\text { January 1, 1940- } \\
\text { September 30, 1970; } \\
\text { August 9, 1986-- } \\
\text { October 8, 2003; } \\
\text { October 1, 2004- } \\
\text { September 30, } 2013\end{array}$ \\
\hline 418.9 & 0.515 & 64.2 & 3.5 & 12.6 & 95.1 & 92.8 & 63.7 & 32.7 & 31.5 & 5.8 & $\begin{array}{c}\text { April 16, 1986- } \\
\text { September 30, } 2013\end{array}$ \\
\hline 193.6 & 0.571 & 68.5 & 4.8 & 8.2 & 93.4 & 91.0 & 68.8 & 38.4 & 24.2 & 5.3 & $\begin{array}{c}\text { November } 1,1929- \\
\text { September 30, 1931; } \\
\text { February 15, 1940- } \\
\text { September 30, 1978; } \\
\text { November 16, 1983- } \\
\text { September 30, } 2013\end{array}$ \\
\hline 334.1 & 0.500 & 56.5 & 3.7 & 14.1 & 95.6 & 93.3 & 53.3 & 26.8 & 42.7 & 5.8 & $\begin{array}{c}\text { July } 18,1967- \\
\text { October } 11,1993\end{array}$ \\
\hline 368.9 & 0.442 & 83.3 & 0.6 & 8.0 & 94.0 & 90.6 & 58.2 & 30.4 & 35.7 & 5.6 & $\begin{array}{c}\text { July } 7,1964- \\
\text { September 30, } 2013\end{array}$ \\
\hline 374.3 & 0.476 & 60.5 & 1.7 & 14.7 & 94.2 & 91.0 & 58.4 & 29.9 & 35.8 & 5.7 & $\begin{array}{c}\text { April 27, 1977- } \\
\text { September 30, } 2013\end{array}$ \\
\hline $1,069.7$ & 0.146 & 62.8 & 0.7 & 17.1 & 92.7 & 88.8 & 55.0 & 31.4 & 38.1 & 5.7 & $\begin{array}{c}\text { June 26, 1901- } \\
\text { September 27, 1902; } \\
\text { December 28, 1902- } \\
\text { December 30, 1903; } \\
\text { April 28, 1937- } \\
\text { February 29, } 1956\end{array}$ \\
\hline
\end{tabular}


Table 1. Description of streamgages located in north Georgia and surrounding States that were evaluated for use in the regional regression analysis for north Georgia.-Continued

[USGS, U.S. Geological Survey; ${ }^{\circ}$, degree; ', minute; ", second. Datum: NAD 27, North American Datum of 1927; NAD 83, North American Datum of 1983. Units: $\mathrm{mi}^{2}$, square mile; in., inch; ft, foot. Variables: DRNAREA, drainage area of basin; PRECIP, mean annual precipitation; ELEV, mean basin elevation, ELEVMAX, maximum basin elevation; ELEVMIN, minimum basin elevation; RRMEAN, relief ratio; LC06FOREST, percentage of basin area covered by forest; LC06SHRUB, percentage of basin area covered by shrub; LC06PAST, percentage of basin area covered by pasture; STASNO4AVE, Average value of percentage by weight of soil material less than 3 inches in size and passing a no. 4 sieve; STASNO10AVE, Average value of percentage by weight of soil material less than 3 inches in size and passing a no. 10 sieve; STASNO200AVE, Average value of percentage by weight of soil material less than 3 inches in size and passing a no. 200 sieve; STATSSILT, average percentage of silt content; STATSSILT, average percentage of sand content; WTDEPAVE, average value of depth to seasonally high water table]

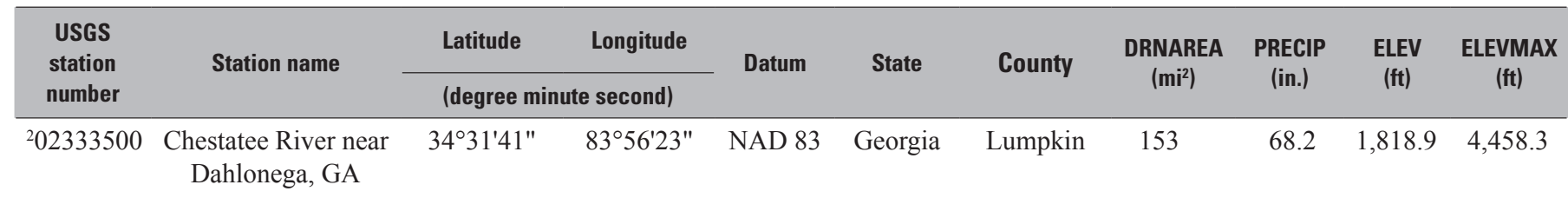

\begin{tabular}{|c|c|c|c|c|c|c|c|c|c|c|}
\hline${ }^{1} 02338523$ & $\begin{array}{l}\text { Hillabahatchee Creek } \\
\text { at Thaxton Rd, } \\
\text { near Franklin, GA }\end{array}$ & $33^{\circ} 20^{\prime} 26^{\prime \prime}$ & $85^{\circ} 13^{\prime} 37^{\prime \prime}$ & NAD 27 & Georgia & Heard & 16.8 & 55.0 & $1,151.8$ & $1,526.0$ \\
\hline${ }^{3} 02339000$ & $\begin{array}{l}\text { Yellowjacket Creek } \\
\text { near Lagrange, GA }\end{array}$ & $33^{\circ} 05^{\prime} 27^{\prime \prime}$ & $85^{\circ} 03^{\prime} 40^{\prime \prime}$ & NAD 27 & Georgia & Troup & 182 & 52.0 & 782.0 & 984.7 \\
\hline${ }^{2} 02340500$ & $\begin{array}{r}\text { Mountain Oak Creek } \\
\text { near Hamilton, GA }\end{array}$ & $32^{\circ} 44^{\prime} 28^{\prime \prime}$ & $85^{\circ} 04^{\prime} 08^{\prime \prime}$ & NAD 27 & Georgia & Harris & 61.7 & 50.4 & 763.7 & $1,304.4$ \\
\hline${ }^{2} 02379500$ & $\begin{array}{l}\text { Cartecay River near } \\
\text { Ellijay, GA }\end{array}$ & $34^{\circ} 41^{\prime} 03^{\prime \prime}$ & $84^{\circ} 27^{\prime} 31^{\prime \prime}$ & NAD 27 & Georgia & Gilmer & 134 & 65.6 & $1,989.7$ & 3,999.4 \\
\hline
\end{tabular}

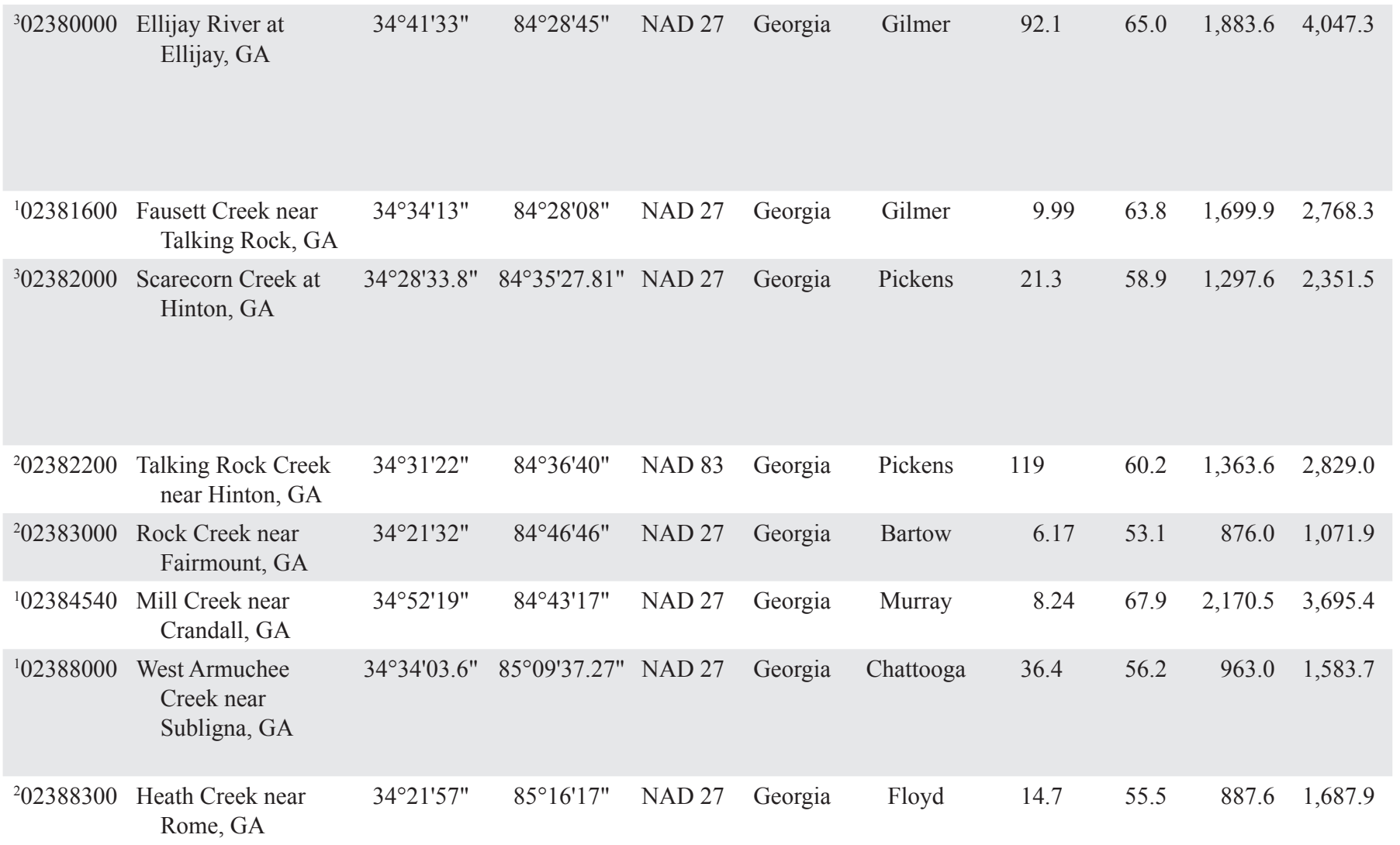


Table 1. Description of streamgages located in north Georgia and surrounding States that were evaluated for use in the regional regression analysis for north Georgia.-Continued

[USGS, U.S. Geological Survey; ${ }^{\circ}$, degree; ', minute; ", second. Datum: NAD 27, North American Datum of 1927; NAD 83, North American Datum of 1983. Units: $\mathrm{mi}^{2}$, square mile; in., inch; ft, foot. Variables: DRNAREA, drainage area of basin; PRECIP, mean annual precipitation; ELEV, mean basin elevation, ELEVMAX, maximum basin elevation; ELEVMIN, minimum basin elevation; RRMEAN, relief ratio; LC06FOREST, percentage of basin area covered by forest; LC06SHRUB, percentage of basin area covered by shrub; LC06PAST, percentage of basin area covered by pasture; STASNO4AVE, Average value of percentage by weight of soil material less than 3 inches in size and passing a no. 4 sieve; STASNO10AVE, Average value of percentage by weight of soil material less than 3 inches in size and passing a no. 10 sieve; STASNO200AVE, Average value of percentage by weight of soil material less than 3 inches in size and passing a no. 200 sieve; STATSSILT, average percentage of silt content; STATSSILT, average percentage of sand content; WTDEPAVE, average value of depth to seasonally high water table]

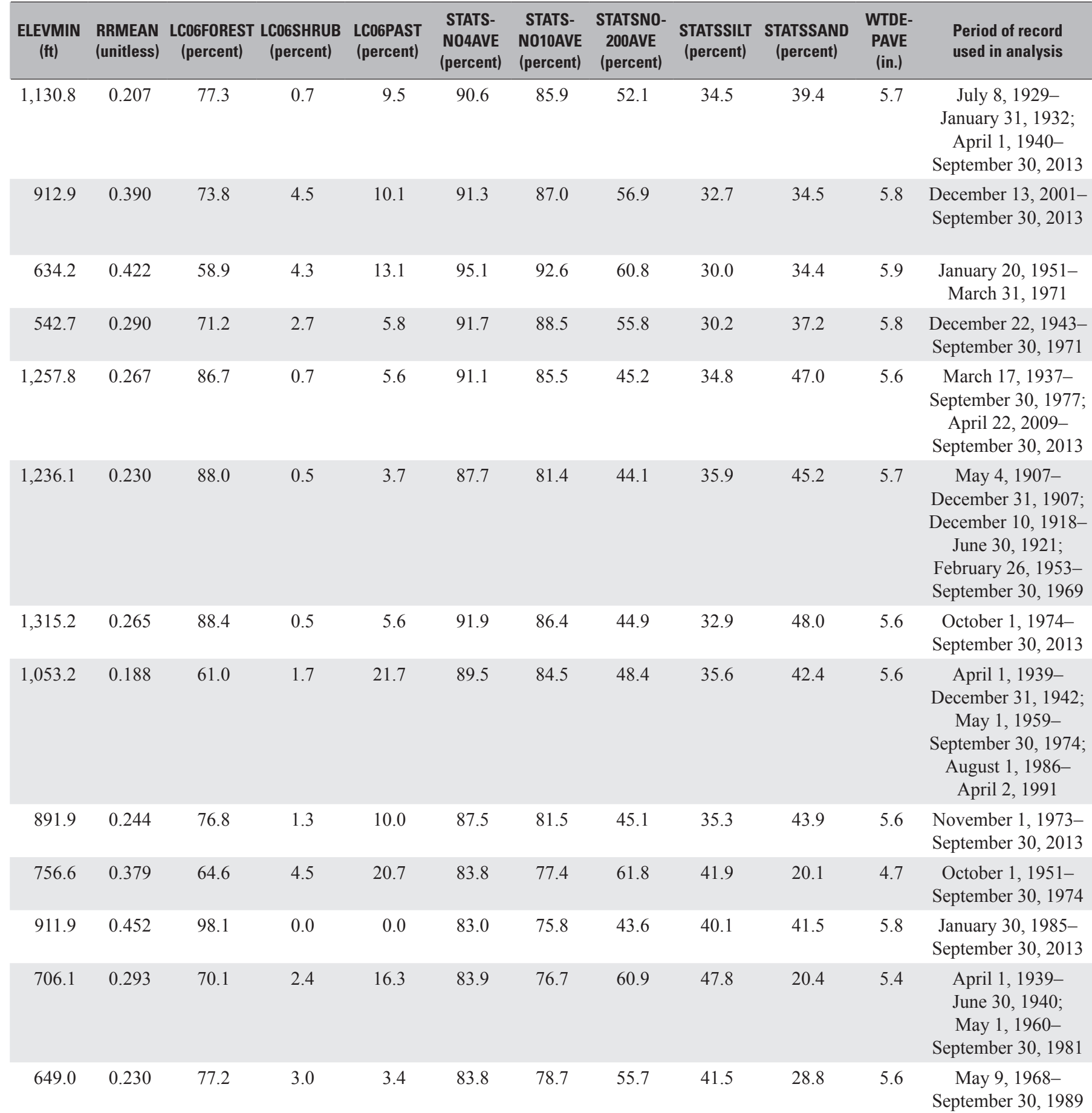


Table 1. Description of streamgages located in north Georgia and surrounding States that were evaluated for use in the regional regression analysis for north Georgia.-Continued

[USGS, U.S. Geological Survey; ${ }^{\circ}$, degree; ', minute; ", second. Datum: NAD 27, North American Datum of 1927; NAD 83, North American Datum of 1983. Units: $\mathrm{mi}^{2}$, square mile; in., inch; ft, foot. Variables: DRNAREA, drainage area of basin; PRECIP, mean annual precipitation; ELEV, mean basin elevation, ELEVMAX, maximum basin elevation; ELEVMIN, minimum basin elevation; RRMEAN, relief ratio; LC06FOREST, percentage of basin area covered by forest; LC06SHRUB, percentage of basin area covered by shrub; LC06PAST, percentage of basin area covered by pasture; STASNO4AVE, Average value of percentage by weight of soil material less than 3 inches in size and passing a no. 4 sieve; STASNO10AVE, Average value of percentage by weight of soil material less than 3 inches in size and passing a no. 10 sieve; STASNO200AVE, Average value of percentage by weight of soil material less than 3 inches in size and passing a no. 200 sieve; STATSSILT, average percentage of silt content; STATSSILT, average percentage of sand content; WTDEPAVE, average value of depth to seasonally high water table]

\begin{tabular}{|c|c|c|c|c|c|c|c|c|c|c|}
\hline $\begin{array}{l}\text { USGS } \\
\text { station } \\
\text { number }\end{array}$ & Station name & Latitude & Longitude & Datum & State & County & $\begin{array}{l}\text { DRNAREA } \\
\qquad\left(\mathrm{mi}^{2}\right)\end{array}$ & $\begin{array}{l}\text { PRECIP } \\
\text { (in.) }\end{array}$ & $\begin{array}{l}\text { ELEV } \\
\text { (ft) }\end{array}$ & $\begin{array}{c}\text { ELEVMAX } \\
\text { (ft) }\end{array}$ \\
\hline${ }^{3} 02389300$ & $\begin{array}{l}\text { Shoal Creek near } \\
\text { Dawsonville, GA }\end{array}$ & $34^{\circ} 25^{\prime} 13^{\prime \prime}$ & $84^{\circ} 08^{\prime} 47^{\prime \prime}$ & NAD 27 & Georgia & Dawson & 21.7 & 63.3 & $1,441.7$ & $1,822.6$ \\
\hline${ }^{1} 02390000$ & $\begin{array}{l}\text { Amicalola Creek } \\
\text { near Dawsonville, } \\
\text { GA }\end{array}$ & $34^{\circ} 25^{\prime} 32^{\prime \prime}$ & $84^{\circ} 12^{\prime} 43^{\prime \prime}$ & NAD 27 & Georgia & Dawson & 89.0 & 65.8 & $1,785.0$ & $3,390.5$ \\
\hline${ }^{3} 02394950$ & $\begin{array}{l}\text { Hills Creek near } \\
\text { Taylorsville, GA }\end{array}$ & $34^{\circ} 04^{\prime} 31.5^{\prime \prime}$ & $84^{\circ} 57^{\prime} 02.68^{\prime \prime}$ & NAD 27 & Georgia & Polk & 25.0 & 52.2 & 955.5 & $1,352.1$ \\
\hline${ }^{1} 02395120$ & $\begin{array}{l}\text { Two Run Creek near } \\
\text { Kingston, GA }\end{array}$ & $34^{\circ} 14^{\prime} 34^{\prime \prime}$ & $84^{\circ} 53^{\prime} 23^{\prime \prime}$ & NAD 83 & Georgia & Bartow & 33.1 & 53.2 & 873.9 & $1,110.6$ \\
\hline${ }^{3} 02397410$ & $\begin{array}{l}\text { Cedar Creek at } \\
\text { GA Ave, at } \\
\text { Cedartown, GA }\end{array}$ & $33^{\circ} 59^{\prime} 45^{\prime \prime}$ & $85^{\circ} 15^{\prime} 53^{\prime \prime}$ & NAD 27 & Georgia & Polk & 65.3 & 54.6 & 940.6 & $1,413.9$ \\
\hline${ }^{1} 02408500$ & $\begin{array}{l}\text { Hatchet Creek near } \\
\text { Rockford, AL }\end{array}$ & $32^{\circ} 56^{\prime} 42^{\prime \prime}$ & $86^{\circ} 13^{\prime} 06^{\prime \prime}$ & NAD 27 & Alabama & Coosa & 233 & 57.2 & 835.7 & $1,919.3$ \\
\hline${ }^{1} 02408540$ & $\begin{array}{l}\text { Hatchet Creek below } \\
\text { Rockford, AL }\end{array}$ & $32^{\circ} 55^{\prime} 00^{\prime \prime}$ & $86^{\circ} 16^{\prime} 13^{\prime \prime}$ & NAD 27 & Alabama & Coosa & 263 & 57.1 & 817.4 & $1,919.3$ \\
\hline${ }^{1} 02410000$ & $\begin{array}{l}\text { Paterson Creek near } \\
\text { Central, AL }\end{array}$ & $32^{\circ} 40^{\prime} 54^{\prime \prime}$ & $86^{\circ} 07^{\prime} 40^{\prime \prime}$ & NAD 27 & Alabama & Elmore & 4.91 & 55.5 & 604.6 & 744.8 \\
\hline${ }^{2} 02411800$ & $\begin{array}{l}\text { Little River near } \\
\text { Buchanan, GA }\end{array}$ & $33^{\circ} 47^{\prime} 51^{\prime \prime}$ & $85^{\circ} 07^{\prime} 03^{\prime \prime}$ & NAD 27 & Georgia & Haralson & 20.2 & 55.1 & $1,241.4$ & $1,447.7$ \\
\hline${ }^{1} 02415000$ & $\begin{array}{r}\text { Hillabee Creek near } \\
\text { Hackneyville, AL }\end{array}$ & $33^{\circ} 03^{\prime} 55^{\prime \prime}$ & $85^{\circ} 52^{\prime} 41^{\prime \prime}$ & NAD 27 & Alabama & Tallapoosa & 190 & 57.4 & 916.1 & $1,555.1$ \\
\hline
\end{tabular}

\begin{tabular}{|c|c|c|c|c|c|c|c|c|c|c|}
\hline${ }^{1} 03439000$ & $\begin{array}{l}\text { French Broad River } \\
\text { at Rosman, NC }\end{array}$ & $35^{\circ} 08^{\prime} 36^{\prime \prime}$ & $82^{\circ} 49^{\prime} 29^{\prime \prime}$ & NAD 83 & $\begin{array}{c}\text { North } \\
\text { Carolina }\end{array}$ & Transylvania & 67.9 & 76.3 & $3,156.4$ & $5,981.0$ \\
\hline${ }^{1} 03441000$ & $\begin{array}{l}\text { Davidson River near } \\
\text { Brevard, NC }\end{array}$ & $35^{\circ} 16^{\prime} 23^{\prime \prime}$ & $82^{\circ} 42^{\prime} 21^{\prime \prime}$ & NAD 83 & $\begin{array}{c}\text { North } \\
\text { Carolina }\end{array}$ & Transylvania & 40.4 & 73.1 & $3,182.2$ & $5,935.0$ \\
\hline
\end{tabular}

\begin{tabular}{|c|c|c|c|c|c|c|c|c|c|c|}
\hline${ }^{1} 03455500$ & $\begin{array}{l}\text { West Fork Pigeon } \\
\text { River above } \\
\text { Lake Logan near } \\
\text { Hazelwood, NC }\end{array}$ & $35^{\circ} 23^{\prime} 46^{\prime \prime}$ & $82^{\circ} 56^{\prime} 15^{\prime \prime}$ & NAD 83 & $\begin{array}{c}\text { North } \\
\text { Carolina }\end{array}$ & Haywood & 27.6 & 74.2 & $4,769.0$ & $6,309.1$ \\
\hline
\end{tabular}


Table 1. Description of streamgages located in north Georgia and surrounding States that were evaluated for use in the regional regression analysis for north Georgia.-Continued

[USGS, U.S. Geological Survey; ’ , degree; ', minute; ", second. Datum: NAD 27, North American Datum of 1927; NAD 83, North American Datum of 1983. Units: $\mathrm{mi}^{2}$, square mile; in., inch; ft, foot. Variables: DRNAREA, drainage area of basin; PRECIP, mean annual precipitation; ELEV, mean basin elevation, ELEVMAX, maximum basin elevation; ELEVMIN, minimum basin elevation; RRMEAN, relief ratio; LC06FOREST, percentage of basin area covered by forest; LC06SHRUB, percentage of basin area covered by shrub; LC06PAST, percentage of basin area covered by pasture; STASNO4AVE, Average value of percentage by weight of soil material less than 3 inches in size and passing a no. 4 sieve; STASNO10AVE, Average value of percentage by weight of soil material less than 3 inches in size and passing a no. 10 sieve; STASNO200AVE, Average value of percentage by weight of soil material less than 3 inches in size and passing a no. 200 sieve; STATSSILT, average percentage of silt content; STATSSILT, average percentage of sand content; WTDEPAVE, average value of depth to seasonally high water table]

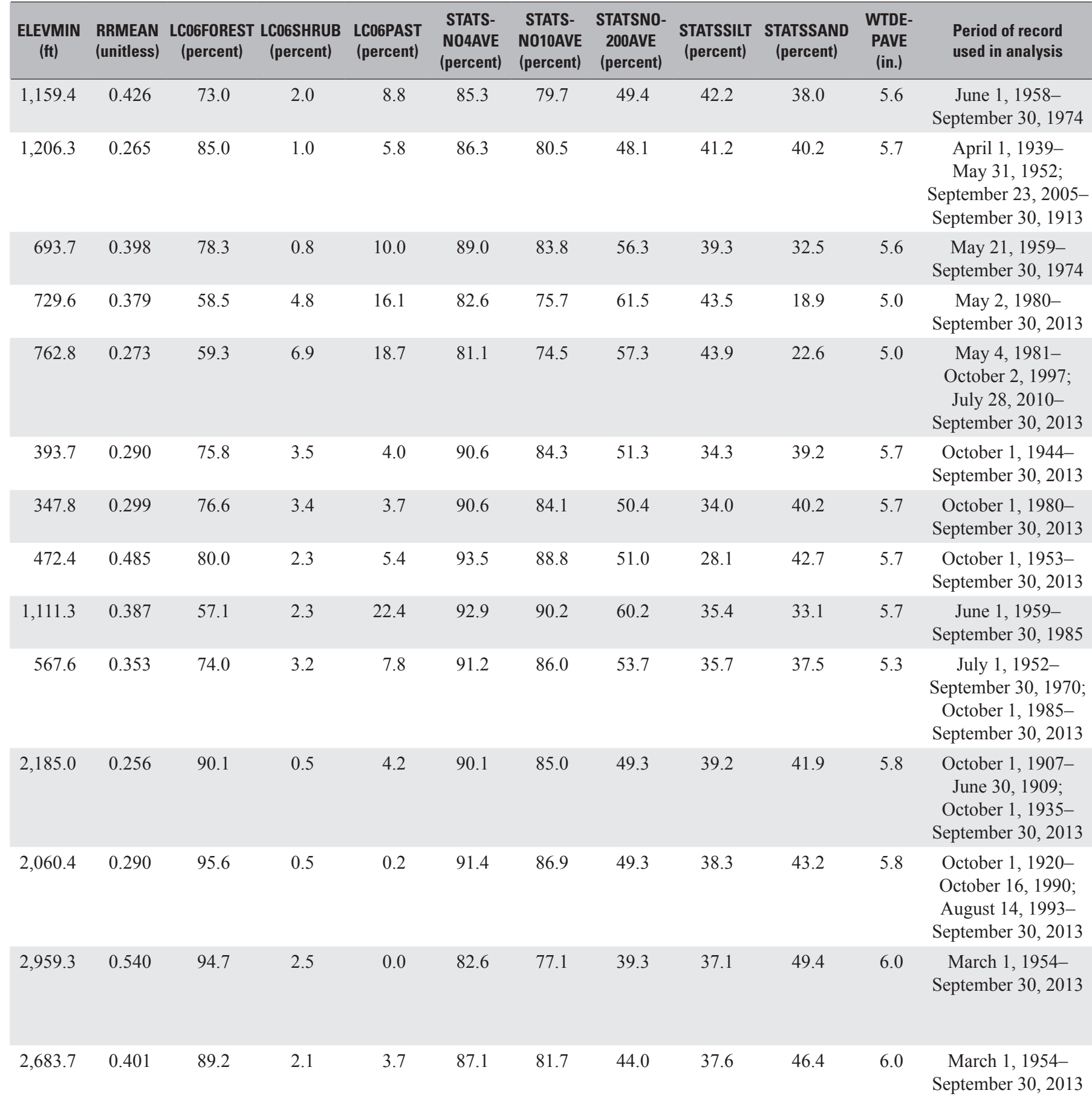


Table 1. Description of streamgages located in north Georgia and surrounding States that were evaluated for use in the regional regression analysis for north Georgia.-Continued

[USGS, U.S. Geological Survey; ${ }^{\circ}$, degree; ', minute; ", second. Datum: NAD 27, North American Datum of 1927; NAD 83, North American Datum of 1983. Units: $\mathrm{mi}^{2}$, square mile; in., inch; ft, foot. Variables: DRNAREA, drainage area of basin; PRECIP, mean annual precipitation; ELEV, mean basin elevation, ELEVMAX, maximum basin elevation; ELEVMIN, minimum basin elevation; RRMEAN, relief ratio; LC06FOREST, percentage of basin area covered by forest; LC06SHRUB, percentage of basin area covered by shrub; LC06PAST, percentage of basin area covered by pasture; STASNO4AVE, Average value of percentage by weight of soil material less than 3 inches in size and passing a no. 4 sieve; STASNO10AVE, Average value of percentage by weight of soil material less than 3 inches in size and passing a no. 10 sieve; STASNO200AVE, Average value of percentage by weight of soil material less than 3 inches in size and passing a no. 200 sieve; STATSSILT, average percentage of silt content; STATSSILT, average percentage of sand content; WTDEPAVE, average value of depth to seasonally high water table]

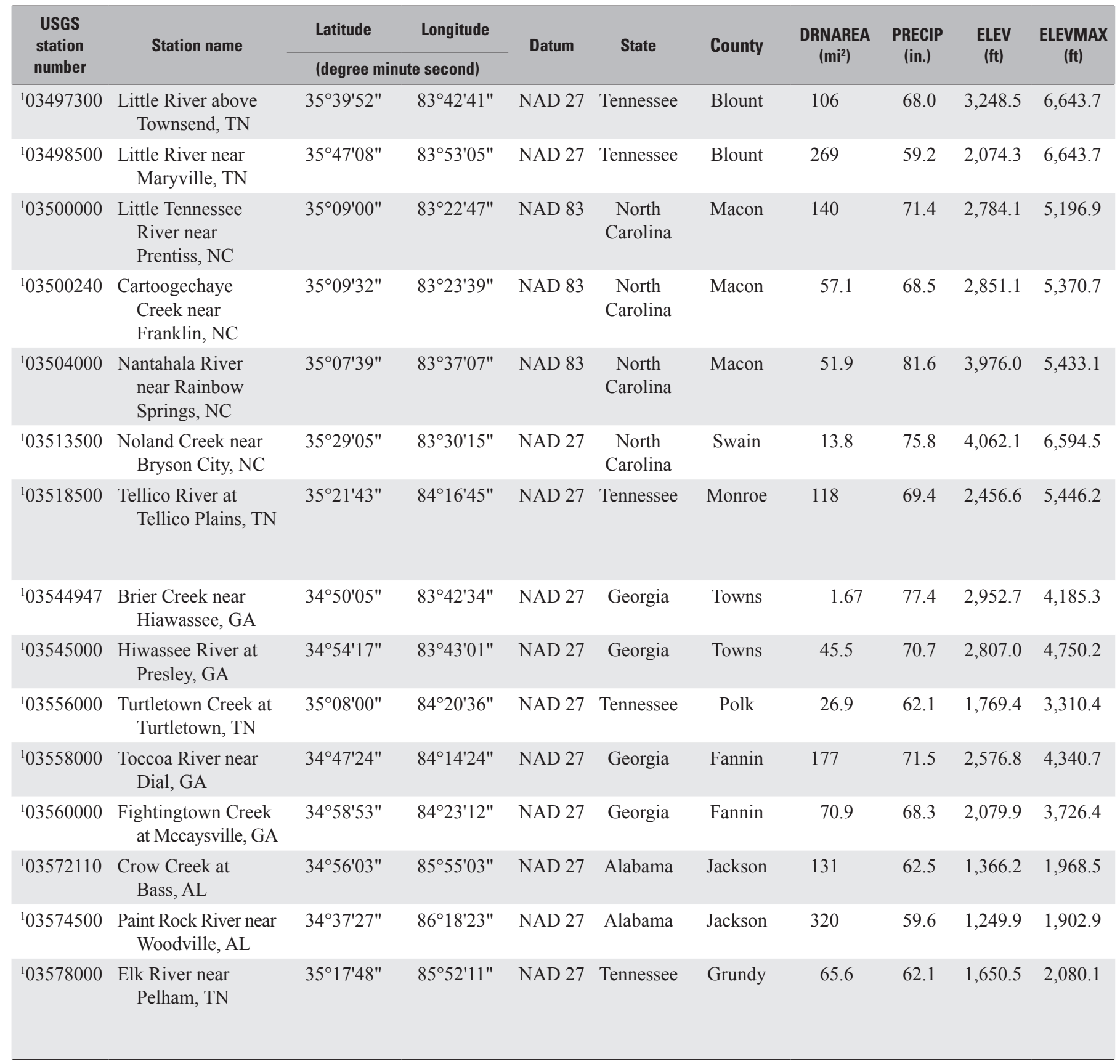

${ }^{1}$ GAGES-II reference streamgage.

${ }^{2}$ GAGES-II nonreference streamgage.

${ }^{3}$ Streamgage not included in GAGES-II database. 
Table 1. Description of streamgages located in north Georgia and surrounding States that were evaluated for use in the regional regression analysis for north Georgia.-Continued

[USGS, U.S. Geological Survey; ’ , degree; ', minute; ", second. Datum: NAD 27, North American Datum of 1927; NAD 83, North American Datum of 1983. Units: $\mathrm{mi}^{2}$, square mile; in., inch; ft, foot. Variables: DRNAREA, drainage area of basin; PRECIP, mean annual precipitation; ELEV, mean basin elevation, ELEVMAX, maximum basin elevation; ELEVMIN, minimum basin elevation; RRMEAN, relief ratio; LC06FOREST, percentage of basin area covered by forest; LC06SHRUB, percentage of basin area covered by shrub; LC06PAST, percentage of basin area covered by pasture; STASNO4AVE, Average value of percentage by weight of soil material less than 3 inches in size and passing a no. 4 sieve; STASNO10AVE, Average value of percentage by weight of soil material less than 3 inches in size and passing a no. 10 sieve; STASNO200AVE, Average value of percentage by weight of soil material less than 3 inches in size and passing a no. 200 sieve; STATSSILT, average percentage of silt content; STATSSILT, average percentage of sand content; WTDEPAVE, average value of depth to seasonally high water table]

\begin{tabular}{|c|c|c|c|c|c|c|c|c|c|c|c|}
\hline $\begin{array}{l}\text { ELEVMIN } \\
(\mathbf{f t})\end{array}$ & $\begin{array}{l}\text { RRMEAN } \\
\text { (unitless) }\end{array}$ & $\begin{array}{c}\text { LCO6FOREST } \\
\text { (percent) }\end{array}$ & $\begin{array}{l}\text { LCO6SHRUB } \\
\text { (percent) }\end{array}$ & $\begin{array}{l}\text { LCO6PAST } \\
\text { (percent) }\end{array}$ & $\begin{array}{l}\text { STATS- } \\
\text { N04AVE } \\
\text { (percent) }\end{array}$ & $\begin{array}{l}\text { STATS- } \\
\text { N010AVE } \\
\text { (percent) }\end{array}$ & $\begin{array}{l}\text { STATSNO- } \\
\text { 200AVE } \\
\text { (percent) }\end{array}$ & $\begin{array}{l}\text { STATSSILT } \\
\text { (percent) }\end{array}$ & $\begin{array}{l}\text { STATSSAND } \\
\text { (percent) }\end{array}$ & $\begin{array}{l}\text { WTDE- } \\
\text { PAVE } \\
\text { (in.) }\end{array}$ & $\begin{array}{l}\text { Period of record } \\
\text { used in analysis }\end{array}$ \\
\hline $1,112.2$ & 0.386 & 99.5 & 0.1 & 0.0 & 90.7 & 83.3 & 49.2 & 42.7 & 41.0 & 5.9 & $\begin{array}{c}\text { October 1, 1963- } \\
\text { September 30, } 2013\end{array}$ \\
\hline 856.3 & 0.210 & 81.3 & 0.5 & 13.4 & 86.7 & 80.4 & 52.5 & 43.3 & 34.0 & 5.8 & $\begin{array}{c}\text { July 1, 1951- } \\
\text { September 30, } 2013\end{array}$ \\
\hline $2,017.7$ & 0.249 & 82.6 & 1.4 & 8.4 & 90.5 & 85.7 & 49.6 & 38.8 & 42.1 & 5.9 & $\begin{array}{c}\text { July 1, 1961- } \\
\text { September 30, } 2013\end{array}$ \\
\hline $3,054.5$ & 0.387 & 97.1 & 0.5 & 0.2 & 89.7 & 85.0 & 46.5 & 37.9 & 45.3 & 6.0 & $\begin{array}{c}\text { October } 1,1940- \\
\text { September } 30,2013\end{array}$ \\
\hline 849.7 & 0.350 & 97.1 & 0.5 & 0.2 & 87.4 & 81.2 & 46.4 & 42.6 & 42.6 & 5.9 & $\begin{array}{c}\text { August 1, 1925- } \\
\text { February 28, 1982; } \\
\text { December 1, 2000- } \\
\text { September 30, } 2013\end{array}$ \\
\hline $2,168.4$ & 0.389 & 99.9 & 0.0 & 0.0 & 89.0 & 82.8 & 44.5 & 38.5 & 46.2 & 5.9 & $\begin{array}{c}\text { May 25, 1984- } \\
\text { September 3, } 2007\end{array}$ \\
\hline $1,936.1$ & 0.309 & 91.7 & 0.6 & 2.8 & 89.5 & 83.4 & 44.7 & 37.7 & 46.4 & 5.9 & $\begin{array}{c}\text { December 1, 1941- } \\
\text { March 31, } 1982\end{array}$ \\
\hline $1,486.2$ & 0.155 & 82.4 & 0.8 & 7.5 & 89.5 & 77.6 & 51.5 & 39.4 & 33.6 & 5.4 & $\begin{array}{c}\text { April 1, 1934- } \\
\text { September 30, } 1971\end{array}$ \\
\hline 554.5 & 0.516 & 82.4 & 3.5 & 8.0 & 87.3 & 82.4 & 63.3 & 45.9 & 23.0 & 5.8 & $\begin{array}{c}\text { January 1, 1936- } \\
\text { September 30, } 2013\end{array}$ \\
\hline 987.5 & 0.607 & 71.8 & 2.3 & 13.8 & 88.7 & 83.8 & 62.6 & 47.7 & 25.3 & 5.6 & $\begin{array}{l}\text { December } 1,1951- \\
\text { December } 16,1987 \text {; } \\
\text { November } 1,2000- \\
\text { September } 30,2013\end{array}$ \\
\hline
\end{tabular}



Manuscript approved January 10, 2016

Prepared by the USGS Science Publishing Network Reston Publishing Service Center Edited by Kay P. Naugle Illustration and layout by Caryl J. Wipperfurth

For additional information regarding this publication, please contact:

Director, South Atlantic Water Science Center

U.S. Geological Survey

720 Gracern Road

Stephenson Center, Suite 129

Columbia, SC 29210

(803) 750-6100

Or visit the South Atlantic Water Science Center Web site at

http://www.usgs.gov/water/southatlantic/ 
